\title{
Temporal scaling and relevance of bivalve nutrient excretion on a tidal flat of the Seto Inland Sea, Japan
}

\author{
Paolo Magni ${ }^{1}$, Shigeru Montani ${ }^{1{ }^{*}}$, Chika Takada ${ }^{1}$, Hiroaki Tsutsumi ${ }^{2}$ \\ ${ }^{1}$ Department of Life Sciences, Kagawa University, 761-0795 Miki, Japan \\ ${ }^{2}$ Faculty of Environmental \& Symbiotic Sciences, PrefecturaI University of Kumamoto, Tsukide 3-1-100, \\ 862-0920 Kumamoto, Japan
}

\begin{abstract}
Using an indirect and integrated approach, we quantified the magnitude and temporal variability of the contribution of macrozoobenthos to the upward flux of inorganic nitrogen and phosphorus on a sandy tidal flat of the Seto Inland Sea, Japan. From April 1994 to April 1996, we conducted monthly field surveys on the abundance and faunal composition of the macrozoobenthic communities inhabiting the lower part of the intertidal zone. Subsequently, we carried out $24 \mathrm{~h}$ day/night laboratory experiments on the nutrient excretion rate by various size-classes of the dominant species. We then obtained the animal nutrient excretion over a $2 \mathrm{yr}$ period, multiplying the species-specific excretion rates by the actual animal biomass found on the tidal flat. Additionally, for all different seasons, we calculated the upward diffusive flux from the sediments from the vertical profiles of nutrient concentrations in the porewater. On the flat, the bivalves Ruditapes philippinarum (Veneridae) and Musculista senhousia (Mytilidae) were dominant, making up $86 \pm 5.6 \%$ when the total biomass exceeded $100 \mathrm{~g} \mathrm{DW}$ (dry weight) $\mathrm{m}^{-2}$. From our laboratory experiments, the mean (day and night) nutrient excretion rates

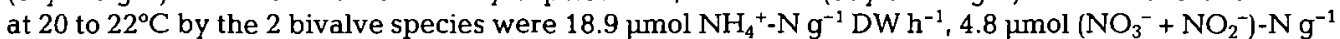
DW h ${ }^{-1}$ and $3.3 \mu \mathrm{mol} \mathrm{PO}_{4}{ }^{3-}-\mathrm{P} \mathrm{g}^{-1} \mathrm{DW} \mathrm{h}^{-1}$. In addition, $\mathrm{NH}_{4}{ }^{+}-\mathrm{N}$ excretion by $R$. philippinarum, but not that by $M$. senhousia, was significantly higher during the day than during the night. This occurred while the food (Thalassiosira sp.) offered in spikes was rapidly taken up irrespective of the concentration (within a field relevant spring-summer range of 10 to $60 \mathrm{\mu g} \mathrm{l}^{-1} \mathrm{chl}$ a) and in day/night treatments. The release of nitrogen (N) and the release of phosphorus (P) were highly correlated with each other, for both $R$. philippinarum and $M$. senhousia, with a N/P ratio of $7.8 \pm 3.0$ and $9.9 \pm 3.5$, respectively. In the field, the bivalve excretion rates of nutrients were calculated to be up to $35.2 \mathrm{mmol} \mathrm{NH}{ }_{4}^{+}-\mathrm{N} \mathrm{m}^{-2} \mathrm{~d}^{-1}$, $8.8 \mathrm{mmol}\left(\mathrm{NO}_{3}{ }^{-}+\mathrm{NO}_{2}{ }^{-}\right)-\mathrm{N} \mathrm{m}^{-2} \mathrm{~d}^{-1}$ and $5.8 \mathrm{mmol} \mathrm{PO}_{4}{ }^{3-}-\mathrm{P} \mathrm{m}^{-2} \mathrm{~d}^{-1}$. These values rank in the upper range of nutrient excretion by intertidal macrozoobenthos and are comparable to those found on dense assemblages ( 800 to $2000 \mathrm{~g}$ ash free $\mathrm{DW} \mathrm{m} \mathrm{m}^{-2}$ ) of the most investigated mussel, Mytilus edulis. In addition, nutrient fluxes through bivalve excretion varied strongly within a few months, up to 10 -fold ( $R$. philippinarum) and 100-fold (M. senhousia) between April 1994 and August 1994, as related to the temporal change of bivalve standing stock. The extent of nutrient regeneration through diffusive flux was comparable to that reported for other intertidal zones of Japan and in the eutrophic Seto Inland Sea, within a range of 0.2 to $1.5 \mathrm{mmol} \mathrm{NH}_{4}^{+}-\mathrm{N} \mathrm{m}^{-2} \mathrm{~d}^{-1}$ and 0.01 to $0.05 \mathrm{mmol} \mathrm{PO}{ }_{4}^{3-}-\mathrm{P} \mathrm{m}^{-2} \mathrm{~d}^{-1}$, thus more than 1 order of magnitude lower than that due to the excretory activity by $R$, philippinarum and $M$. senhousia. Our results indicate that the dominant bivalves, $R$. philippinarum and $M$. senhousia, play a major role in the processes of benthic nutrient regeneration within the intertidal zone, rapidly and efficiently recycling the inorganic forms of $\mathrm{N}$ and $\mathrm{P}$ available to primary producers. This study highlighted the importance of considering the temporal scaling of intertidal macrozoobenthos distribution in the quantification of the processes of benthic nutrient regeneration in these highly variable systems.
\end{abstract}

KEY WORDS: Bivalve excretion - Ruditapes philippinarum $\cdot$ Musculista senhousia $\cdot$ Benthic nutrient regeneration S Scale $\cdot$ Diffusive flux $\cdot$ Nitrogen $\cdot$ Phosphorus $\cdot$ Tidal flat $\cdot$ Seto Inland Sea

\section{INTRODUCTION}

Benthic nutrient regeneration is a major driving force in the dynamics of biophilic elements in coastal

\footnotetext{
•Corresponding author. E-mail: montani@ag.kagawa-u.ac.jp
}

marine ecosystems (Rowe et al. 1975, Nixon 1981. Klump \& Martens 1983). It has been shown that the macrozoobenthos, particularly dense assemblages of bivalves, play a fundamental role in these processes through their excretory products (Jordan \& Valiela 1982, Murphy \& Kremer 1985, Prins \& Smaal 1994). To 
quantify such a role, several studies have been conducted in the last $15 \mathrm{yr}$ on the animal excretory activity through laboratory and mesocosm experiments (Doering et al. 1987, Nakamura et al. 1988, Kiibus \& Kautsky 1996), in situ benthic chambers and sediment core incubations (Yamada \& Kayama 1987, Gómez-Parra \& Forja 1993, Yamamuro \& Koike 1993), and open flow systems (Dame et al. 1984, Asmus et al. 1990, 1994, Prins \& Smaal 1990). In the field, a common approach includes the quantification of the total upward flux of nutrients from the sediments and the subsequent estimation of the relative contribution of animal excretion. This requires additional information on species composition and animal biomass in the substrate and animal species-specific excretion rates and/or respiratory metabolism (Murphy \& Kremer 1985, Prins \& Smaal 1994). However, uncertainty about the actual contribution of animal excretion to the total flux may still remain due to the additional effect of local variables. These include nutrient release due to microbial mineralization of vegetative detritus (Falcao \& Vale 1990) and animal biodeposits (Henriksen et al. 1983, Gardner et al. 1993, Smaal \& Zurburg 1997). The nutrient release from sediments may also be enhanced by bioturbation and irrigation currents due to benthic infauna species (Callender \& Hammond 1982, Henriksen et al. 1983, Yamada \& Kayama 1987, Aller 1988, Luther et al. 1998). In contrast, the extent of excretory processes may be underestimated due to microalgal (Rizzo 1990, Sundbäck et al. 1991, Risgaard-Petersen et al. 1994) or, usually to a smaller degree, in situ bacterial (van Duyl et al. 1993) nutrient uptake.

Further, a factor which has been given little attention in quantifying the animal contribution to the processes of nutrient regeneration is the temporal variability of the macrozoobenthic communities. In intertidal zones, major studies on the release of nutrients by dense populations of bivalves have been based on 1 (Dame et al. 1984, Dame \& Dankers 1988) or relatively few sampling occasions (Prins \& Smaal 1994, Smaal \& Zurburg 1997). Other studies have investigated the year-round seasonal variation of animal nutrient excretion through in situ chamber incubations (Yamada \& Kayama 1987, Boucher \& Boucher-Rodoni 1988, Schlüter \& Josefsen 1994). However, experimental animals were used in short period incubations and no or little information on the actual animal composition and biomass in the specific study area was given. Extended information on the temporal change of natural populations of intertidal macrozoobenthos is often neglected, but this might be fundamental in assessing the role of macrozoobenthos in the year-round processes of nutrient regeneration within the intertidal zone. Strong temporal change of animal standing stock may possibly surpass the effect and importance of variation in excretion rate due to animal physiological factors, such as seasonal cycles of gametogenesis, storage and utilization of body reserves, and water temperature (Bayne \& Scullard 1977, Schlüter \& Josefsen 1994).

This study is part of a multidisciplinary project which aims to quantify the cycling of biophilic elements $\left(C_{1}\right.$ $N, P, S i$ in a tidal estuary of the Seto Inland Sea, Japan, and to assess the role of macrozoobenthos in this cycling. As an initial phase of this project, we quantified the standing stock of intertidal microphytobenthos and estimated its primary production (Magni \& Montani 1997). Further, we assessed the short-term (24 h) and seasonal $(2 \mathrm{yr})$ variability of the water chemistry along the estuary (Montani et al. 1998, Magni \& Montani 2000). In parallel, we conducted field surveys, on both the intertidal and the subtidal zones, to evaluate the factors controlling the spatial/temporal variability of the autochthonous macrozoobenthic communities (Magni \& Montani 1998).

In the present work, we aimed to quantify the magnitude and temporal scaling of upward flux of $\mathrm{NH}_{4}{ }^{+}-\mathrm{N}$, $\left(\mathrm{NO}_{3}{ }^{-}+\mathrm{NO}_{2}{ }^{-}\right)-\mathrm{N}$ and $\mathrm{PO}_{4}{ }^{3-}-\mathrm{P}$ from intertidal sediments due to the excretory activity of macrozoobenthos and to evaluate its relevance in the cycling of the inorganic forms of 2 major bioelements such as $N$ and P. Our indirect and integrated approach included laboratory measurements of nutrient excretion rates by 2 dominant bivalve species (Ruditapes philippinarum and Musculista senhousia). These rates were applied to a field (community) situation on a tidal flat, where we investigated the faunal composition and temporal distribution of macrozobenthos over a 2 yr period.

\section{MATERIALS AND METHODS}

Bi-annual field survey. We conducted the field survey on an intertidal flat in the Seto Inland Sea, southwestern Japan (Fig. 1). The sediment in our study area is sandy, with a mud fraction $(<0.063 \mu \mathrm{m})$ lower than $2 \%$ (Magni \& Montani 1997). Sampling was carried out at low tide from April 1994 to April 1996, fortnightly (May 16 and 30, and September 7 and 29, 1995) to monthly (the other periods). At each occasion, we recorded the temperature of emerged surface sediment and ebbing water (ca $40 \mathrm{~cm}$ depth) (Stn $\mathrm{H} 1$, Fig. 1). The temperature values of both ebbing water and surface water at an adjacent subtidal station (Stn Y3, Fig. 1) are those from an associated piece of work (Magni \& Montani 2000). We assumed the latter measurement to be the water temperature on the intertidal flat during the sediment emersion (ca $20 \mathrm{~h} \mathrm{~d}^{-1}$ ). For the determination of the macrozoobenthos, we set a transect line of 5 stations (Stns B5 to B1, Fig. 1) between the LWL (low water level) and the ELWS 


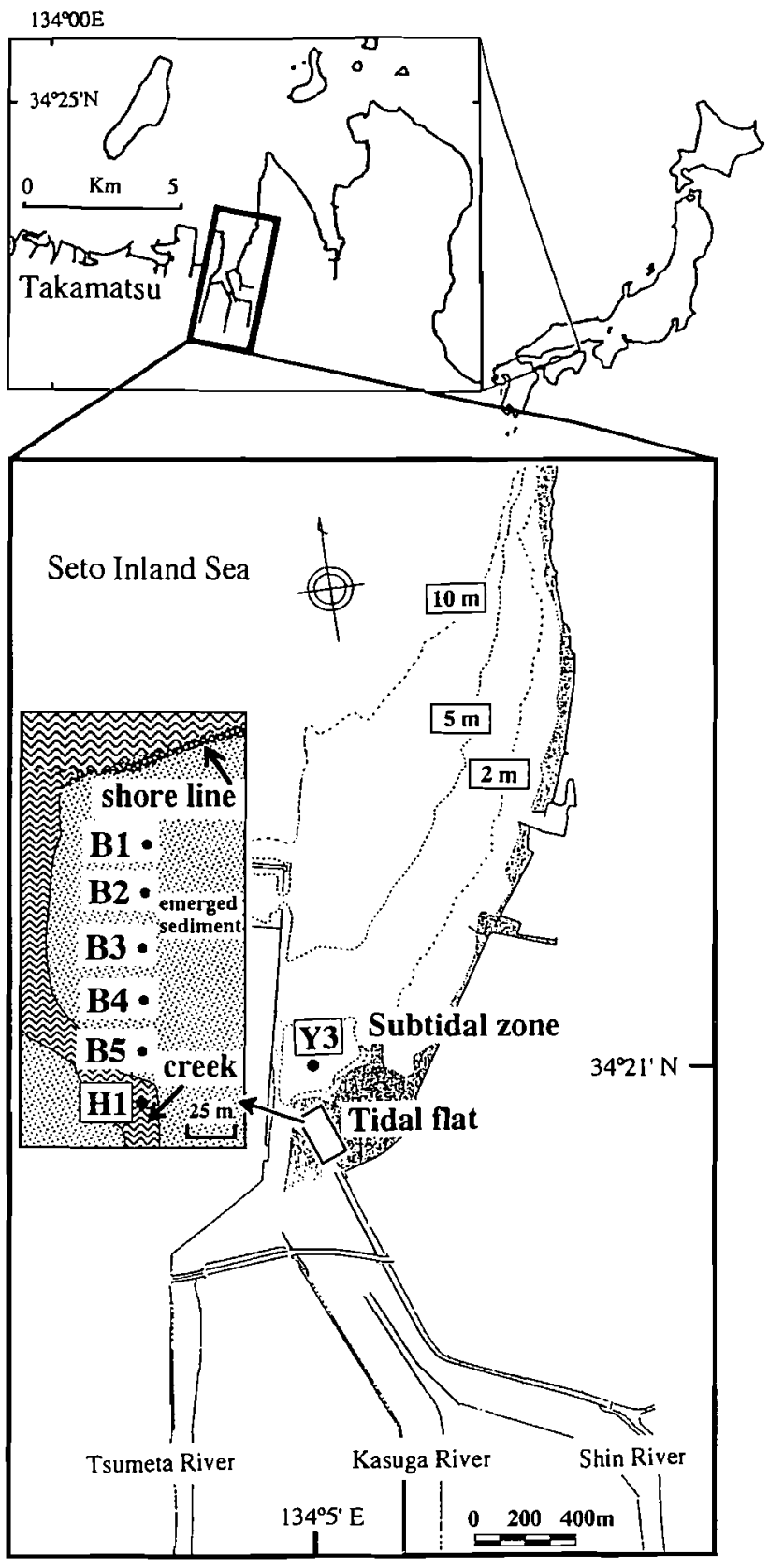

Fig. 1. Study area and location of the sampling stations. Stn $\mathrm{H} 1$ (mean water depth of $40 \mathrm{~cm}$ at low tide) was set at an ebbing tidal creek close to the 5 emerged intertidal stations (Stns B5 to B1) where the macrozoobenthos was collected. Stn Y3 was set at the innermost part of an adjacent subtidal zone

(extreme low water spring tide). At these stations, we collected duplicate sediment samples using a $10 \mathrm{~cm}^{3}$ stainless steel core and sieved them on a mesh size of $1 \mathrm{~mm}$. The residue was fixed in a Rose Bengal $10 \%$ formalin solution for the determination of the macrozoobenthos ('large' macrofauna). In the laboratory, the macrozoobenthos was separated from the residue and transferred into a $75 \%$ ethanol and $2.5 \%$ ethyleneglycol solution. The animals were sorted and counted under a stereo-microscope (Olympus, Wild M3Z). They were weighed as a total wet weight (WW), including the shell for bivalves. The total biomass of Ruditapes philippinarum and Musculista senhousia from each sample was then transformed to a dry weight (DW) biomass of the soft tissues using the equations described in the next section. The DW biomass of polychaetes and that of other minor and/or uncommon taxa was calculated as $20 \%$ of their WW biomass (Ricciardi \& Bourget 1998). Through the 2 yr field work, we conducted 27 samplings and collected 131 samples in duplicate (Stn B1 was not sampled in August and September 1994 and March and April 1995). In the present study, we report the mean density and biomass of macrozoobenthos collected at Stns B5 to B1 as representative of the monthly natural abundance and faunal composition on the intertidal flat under investigation.

Bivalve length/soft tissue relationship. From the intertidal flat where we carried out the bi-annual field survey, we collected randomly in different seasons a total of 291 and 155 individuals of Ruditapes philippinarum and Musculista senhousia, respectively. In the laboratory, the length of each animal was measured to the nearest $0.1 \mathrm{~mm}$ with a digital caliper and the total weight (live animal) was determined. All specimens were then depurated in filtered (Whatman GF/F) sea water, with no sediment, for 6 to $8 \mathrm{~h}$. After this operation, the soft tissues of each animal were removed from the shell, gently dried on blotting paper and weighed (wet weight). Subsequently, the soft tissues were freeze dried and weighed again to the nearest $1 \mathrm{mg}$ DW. For each bivalve species, we obtained a linear equation of the plots of total weight versus DW soft tissues from all samples (Fig. 2a,b). We used these equations to calculate the DW bivalve biomass of the animal samples collected during the field survey, as 3.6 and $4.7 \%$ of the total (live) weight for $R$. philippinarum and $M$. senhousia, respectively (Fig. 2a,b).

Laboratory experiments: experimental setup and procedure. Subsequent to the field survey, on May 910 and September 6-7, 1996, we conducted laboratory experiments on the nutrient excretion rate by the dominant species, such as the bivalves Ruditapes philippinarum and Musculista senhousia (see 'Results'). On both occasions, the experiment consisted of 2 successive treatments lasting $10 \mathrm{~h}$ each. The first treatment was carried out during the day, the second one at night. A $2 \mathrm{~h}$ interval elapsed between treatments.

We employed $25 \mathrm{~cm}$ high $\times 15 \mathrm{~cm} \varnothing$ PVC aquaria provided with an output pipe (15 mm length, $5 \mathrm{~mm} \varnothing)$ at their base. An upper removable cover was connected to a silicone tube $(5 \mathrm{~mm} \varnothing)$ for the bubbling air supply. The incoming air was passed through a 


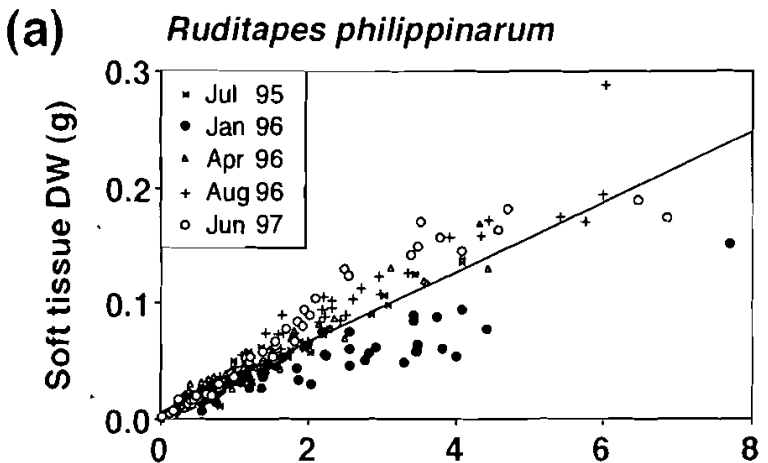

(b)

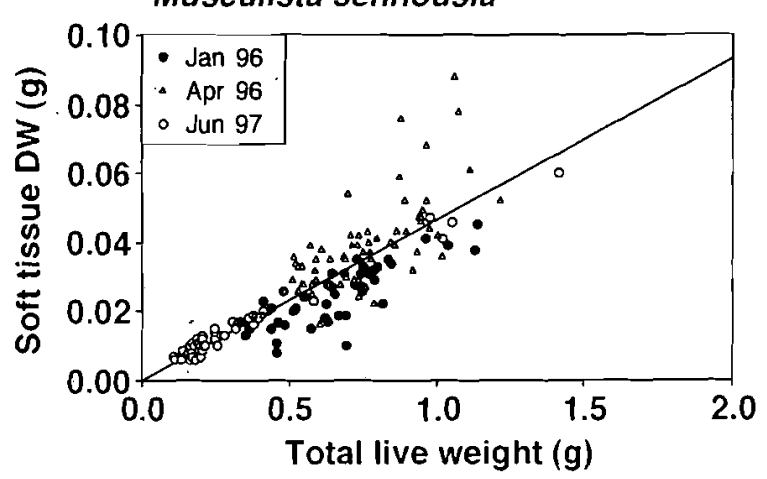

Fig. 2. Relationship between soft tissue expressed as dry weight (DW) and total weight (living animal) for (a) Ruditapes philippinarum (linear regression line: $y=0.030 x+0.006, \mathrm{r}^{2}=$ $0.844 ; \mathrm{n}=291$ ) and (b) Musculista senhousia (linear regression line: $y=0.047 x, r^{2}=0.726 ; n=155$ )

$0.45 \mu \mathrm{m}$ filter (Ekicrodisc) to avoid contamination from impurities. Aquaria and sampling materials were cleaned with $1 \mathrm{~N} \mathrm{HCl}$ for $1 \mathrm{~d}$ prior to use. Sandy surface sediment, subsurface water (salinity $30 \mathrm{psu}$ ) and animals used in the experiments were collected from the same tidal flat as those in our field survey. The sediment was sieved and sorted to a grain size of $250 \mu \mathrm{m}<$ $\varnothing<1 \mathrm{~mm}$; washed, dried at $160^{\circ} \mathrm{C}$ for $20 \mathrm{~h}$, and at heated to $500^{\circ} \mathrm{C}$ for $2 \mathrm{~h}$, to remove the organic matter. The water was filtered first through $0.7 \mu \mathrm{m}$ glass fiber filters (Whatman GF/F) and then through $0.45 \mu \mathrm{m}$ filters (Millipore HA). The animals were collected $20 \mathrm{~h}$ prior to each experiment. They were cleaned and measured for length and total wet weight. Subsequently, they were depurated in separated buckets containing filtered sea water with no sediment for 6 to $8 \mathrm{~h}$. Eight hours before the experiments, the sorted sediment was washed in filtered sea water and placed into each aquarium $(5 \mathrm{~cm}$ thickness). Within the aquarium, the output pipe was fitted with a $100 \mu \mathrm{m}$ plankton net to avoid loss of sediment during water changing operations. Subsequently, $1 \mathrm{l}$ of filtered sea water was added and aerated, and animals of similar size were homoge- neously distributed within the aquarium to acclimatize (no food was given). On each occasion, an aquarium with sediment and filtered sea water but no animal was used as a control. Two hours before starting the experiments, the water was simultaneously discharged from the bottom output of all aquaria. The animals were not removed and a low tide condition was kept until the start. This was to simulate the field situation, where we calculated that there was approximately $2 \mathrm{~h}$ of sediment emersion for each tidal cycle (mixed-semidiurnal type).

At the start of each experiment, $2.5 \mathrm{l}$ of new filtered water were gently added from above, paying attention not to disturb the sediment. Within about $10 \mathrm{~min}$, a high tide condition was reached. A known amount of phytoplankton was then introduced as a spike into each aquarium. We used Thalassiosira sp. as a food, which had been cultured in enriched medium containing $120 \mathrm{mg} \mathrm{l}^{-1} \mathrm{NaNO}_{3}(1.41 \mathrm{mmol}), 5 \mathrm{mg} \mathrm{l}^{-1}$ $\mathrm{K}_{2} \mathrm{HPO}_{4}(0.029 \mathrm{mmol})$ and $33 \mathrm{mg} \mathrm{I}{ }^{-1} \mathrm{NaSiO}_{3} \cdot 9 \mathrm{H}_{2} \mathrm{O}$ $(0.27 \mathrm{mmol})$. The phytoplankton spike was concentrated in $5 \mathrm{ml}$ of medium to limit the artificial increase of nutrient concentrations during the course of the experiments. After the spike of food, the water column was gently mixed to homogeneously distribute the phytoplankton. Immediately after, $80 \mathrm{ml}$ water samples were collected from each aquarium. A subsample of $50 \mathrm{ml}$ was filtered through $0.7 \mu \mathrm{m}$ glass fiber filters (Whatman GF/F) for chlorophyll a (chl a) determination. Three additional subsamples were collected $(10 \mathrm{ml}$ each), 2 were filtered $(0.45 \mu \mathrm{m})$ and stored at $-20^{\circ} \mathrm{C}$ for the determination of nutrients in the dissolved phase. The third sample was immediately fixed in $1 \%$ neutral formaline solution for phytoplankton cell counting. Sampling was carried out every $2 \mathrm{~h}$. In addition, a sample for chl a determination and cell number counting was taken $30 \mathrm{~min}$ after the spike. In each aquarium, a second spike of food was given after $6 \mathrm{~h}$. At this time, water samples were collected just before and after introduction of the food to take into account possible artificial increase in nutrient concentrations due to the addition of phytoplankton culture medium. After the $10 \mathrm{~h}$ day (light) treatment, the remaining water in each aquarium (ca $80 \%$ of the initial volume) was slowly discharged from the output. A low tide condition was re-established for ca $2 \mathrm{~h}$ (as before the start of the experiment). The bivalves were not removed so that there was continuity from the day to the night (dark) treatment, which was carried out in the same way as the day treatment. At the end of the night treatment, the animals were removed from the sediment and depurated. Then, their soft tissues were separated from the shell, freezedried and weighed to determine the animal DW, as described above. 
Sample analysis. Chl $a$ was extracted in $90 \%$ acetone solution and spectrophotometrically analyzed according to Lorenzen's (1967) method, as described by Parsons et al. (1984). Cell counts were performed on $0.1 \mathrm{ml}$ subsamples in triplicate. The linear regression was represented by the equation chl $a=0.01 \times$ cell count +3.6 , $r^{2}=0.908(p<0.001, n=40$, plots not shown). Nutrient concentrations $\left[\mathrm{NH}_{4}{ }^{+}-\mathrm{N},\left(\mathrm{NO}_{3}{ }^{-}+\mathrm{NO}_{2}{ }^{-}\right)-\mathrm{N}\right.$ and $\mathrm{PO}_{4}{ }^{3-}{ }^{-} \mathrm{P}$ ] were determined with a Technicon autoanalyzer II, according to Strickland \& Parsons (1972).

Calculation of bivalve excretion rate. The nutrient concentrations measured during the course of each treatment were corrected according to the change in nutrient concentrations in the control and a possible artificial increase after each spike (see above). Each value was then multiplied by the water volume at the sampling time and divided by the total DW biomass of the experimental bivalves. Thus, the nutrient concentrations measured at regular $2 \mathrm{~h}$ intervals from time 0 to time $10 \mathrm{~h}$ were normalized with respect to animal biomass in each

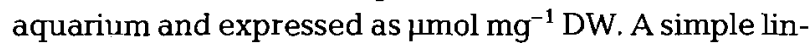
ear regression was then obtained for the nutrient concentrations so calculated. The bivalve nutrient excretion rate $\left(\mu \mathrm{mol} \mathrm{g}^{-1} \mathrm{DW} \mathrm{h}^{-1}\right)$ was calculated for each size-class and day/night treatments from the relevant regression line after statistical analysis for significance (see below).

Vertical profile of nutrients in the porewater and calculation of diffusive fluxes. On the intertidal flat, we additionally collected emerged sediment samples at 7 to 8 sites at Stn B5 using an acrylic core tube $3 \mathrm{~cm}$ inner diameter) gently pushed by hand into the sediment. The surface $(0-0.5 \mathrm{~cm})$, the sub-surface $(0.5-2 \mathrm{~cm})$ and deeper layers (each of $1 \mathrm{~cm}$ thickness to a depth of $10 \mathrm{~cm}$ ) of the sediments were carefully extruded and sliced. Sediment samples from the same layer were pooled together and brought to the laboratory within $2 \mathrm{~h}$ for further treatment and chemical analysis (Magni 1998). This included the determination of sediment porosity, as measured by the water content (obtained after drying sediment subsamples at $105^{\circ} \mathrm{C}$ for $20 \mathrm{~h}$ ). The remaining sediment was then centrifuged at $3000 \mathrm{rpm}(1000 \times \mathrm{g})$ for $20 \mathrm{~min}$. The extracted porewater was filtered on disposable filters $(0.45 \mu \mathrm{m})$ fitted to a $10 \mathrm{ml}$ syringe. The filtrate was stored at $-20^{\circ} \mathrm{C}$ for nutrient analysis, which was carried out within 2 to $3 \mathrm{wk}$. Some samples from the surface layer were not analyzed for all nutrient species due to an insufficient amount of extracted porewater. In the present study, we limit the presentation of results to the uppermost $5 \mathrm{~cm}$ of the sediment samples collected in January, April, July and October 1995. We will present in a subsequent paper a more detailed description of the seasonal change of nutrient concentrations in the porewater of intertidal sediments on the tidal flat under investigation (Magni et al. unpubl.).
We calculated the upward fluxes of nutrients using the diagenetic model (Fick's first law) described by Berner (1980), according to the following equation:

$$
J_{\mathrm{D}}=-\phi D s(\partial C / \partial X)
$$

where $J_{\mathbf{D}}$ is the diffusive flux ( $\left.\mathrm{mmol} \mathrm{m} \mathrm{m}^{-2} \mathrm{~d}^{-1}\right), \phi$ is the porosity of the sediment $(0.68$ to 0.73$), D s$ is the diffusion coefficient, $C$ is the concentration in the porewater and $X$ is the depth of the sediment. For $D s$ we used $9.8 \times 10^{-6} \mathrm{~cm}^{2} \mathrm{~s}^{-1}$ and $3.6 \times 10^{-6} \mathrm{~cm}^{2} \mathrm{~s}^{-1}$ for ammonium and phosphate, respectively (Krom \& Berner 1980).

Statistical analysis. Statistical analysis was carried out using the MSTAT-C statistical package. A simple linear regression (e.g. bivalve nutrient excretion rate, diffusive flux from the vertical profiles of nutrient concentrations in the porewater) and a 2-way ANOVA (i.e. day/night food uptake) were used to test the significance of the results. To evaluate differences in bivalve nutrient excretion between day and night treatments, the data sets were subjected to ANOVA in a 2 factor randomized complete block design, using the day' night variable as a factor $A$, the time (hour) variable as a factor $B$ and the size-classes of each bivalve species as replicates.

\section{RESULTS}

\section{Bi-annual field survey}

The temperature of emerged surface sediment varied from 2.8 (December 1995) to $30.8^{\circ} \mathrm{C}$ (July 1994) (Stns B5 to B1, Fig. 3). It closely approximated the temperature of surface ebbing water, which varied from 3.6 to $32.2^{\circ} \mathrm{C}$ (December 1995 and July 1994, respectively) (Stn H1, Fig. 3). At Stn Y3, the seasonal variation of temperature was more restricted, varying from 8.0 (February 1996) to $26.4^{\circ} \mathrm{C}$ (July 1994) (Fig. 3).

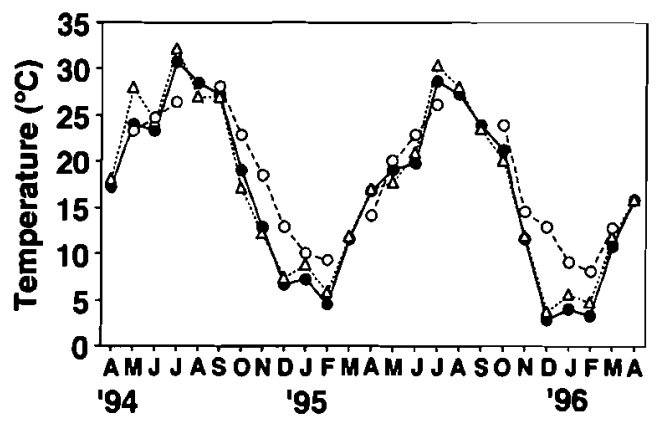

Fig. 3. Temporal variation of temperature at the emerged surface sediments at Stns B5 to B1 (- - , and at Stns H1 $(-\cdots-\Delta-\cdots)$ and Y3 (---O-..) 
(a)

$$
\begin{aligned}
& \square \text { Others } \\
& \square \text { Cirriformia tentaculata } \\
& \text { Nereris sp. } \\
& \text { Ruditapes philippinarum } \\
& \text { Musculista senhousia }
\end{aligned}
$$

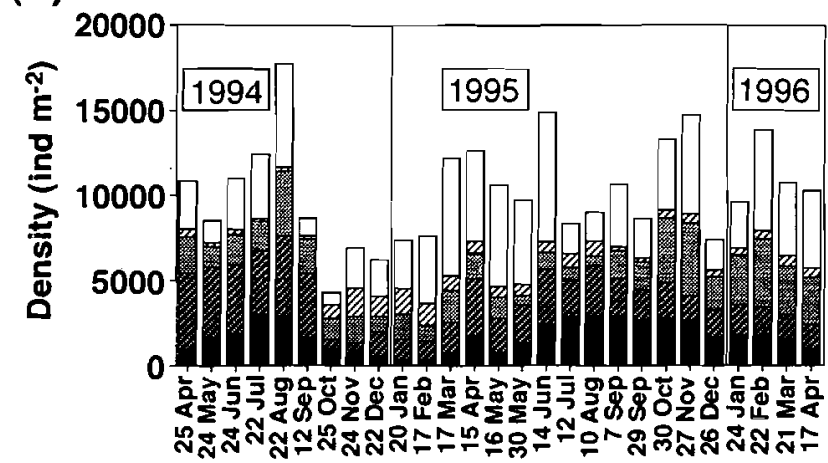

(b)

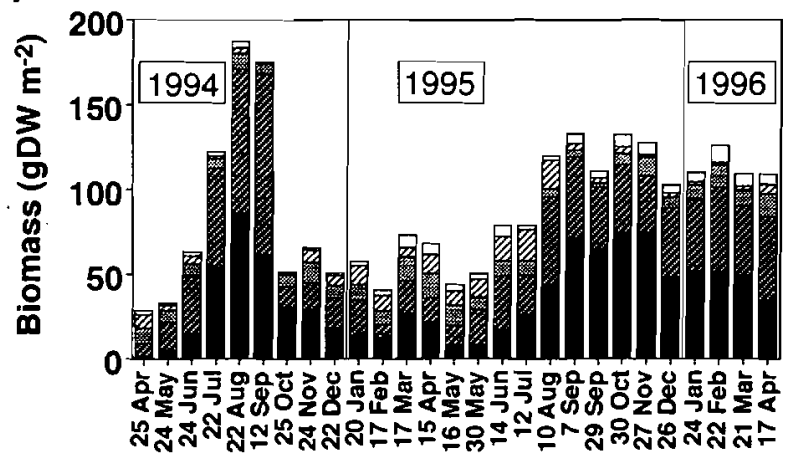

Fig. 4. Field survey: seasonal change of (a) density and (b) biomass of the macrozoobenthic communities (monthly average of duplicate samples collected at Stns B5 to B1). Note that in May 1995 and September 1995 sampling was carried fortnightly
The density (Fig. 4a) and biomass (Fig. 4b) of macrozoobenthos varied from $4280 \pm 3956$ (October 1994) to $17750 \pm 2003$ ind. $\mathrm{m}^{-2}$ (August 1994), and from $8.1 \pm$ 5.7 (April 1994) to $186.9 \pm 32.7 \mathrm{~g} \mathrm{DW} \mathrm{m}^{-2}$ (August 1994), respectively. The bivalves Ruditapes philippinarum and Musculista senhousia and the polychaetes Nereis sp. and Cirriformia tentaculata were dominant (Fig. 4). Over the 2 yr period, the contribution of $R$. philippinarum and $M$. senhousia to the total density and biomass was 39 and $73 \%$, respectively. From July to September 1994 and from August 1995 to April 1996 the total biomass exceeded $100 \mathrm{~g} \mathrm{DW} \mathrm{m}^{-2}$ (Fig. $4 \mathrm{~b}$ ), and the 2 bivalve species most remarkably accounted for $86.2 \pm 5.6 \%$ of this. Both $R$. philippinarum and $M$. senhousia showed a marked temporal variability. In 1994, the biomass of $M$. senhousia increased from 1.0 (April) to $85.7 \mathrm{~g} \mathrm{DW} \mathrm{m}^{-2}$ (August) and that of $R$. philippinarum increased from 8.1 (April) to $106.7 \mathrm{~g} \mathrm{DW} \mathrm{m}^{-2}$ (September). In October 1994, dystrophic events related to the rapid decomposition of a high macroalgal biomass (Ulva sp.), covering the flat during spring-summer, caused a crash of $R$. philippinarum (Magni \& Montani 1998) (Fig. 4). The decline $M$. senhousia was more progressive through the next few months. Subsequently, in 1995, R. philippinarum did not attain a biomass as high as in 1994 (maximum of $52.1 \mathrm{~g} \mathrm{DW} \mathrm{m}^{-2}$ in August 1995) and $M$. senhousia prevailed with an increase from 7.2 (May 16, 1995) to $74.2 \mathrm{~g} \mathrm{DW} \mathrm{m}^{-2}$ (October 1995). Over the whole period, the biomasses of $R$. philippinarum and $M$. senhousia were of the same order of magnitude, averaging $34.8 \pm$ 23.2 and $36.5 \pm 24.5 \mathrm{~g} \mathrm{DW} \mathrm{m}^{-2}$, respectively. However, their variability during the 2 subsequent spring-summer and autumn-winter periods was remarkable (Fig. 4).

\begin{tabular}{|c|c|c|c|c|c|c|c|c|}
\hline Species & & $\begin{array}{l}\text { Size } \\
(\mathrm{mm})\end{array}$ & Ind. & $\begin{array}{l}\text { TOT } \\
\text { (mg) }\end{array}$ & $\begin{array}{l}\text { DW } \\
(\mathrm{mg})\end{array}$ & $\begin{array}{l}\text { Temp } \\
\left({ }^{\circ} \mathrm{C}\right)\end{array}$ & $\begin{array}{c}\text { Chl a } \\
\left(\mu \mathrm{g} \mathrm{l}^{-1}\right)\end{array}$ & $\begin{array}{l}\text { Expt } \\
\text { (Date) }\end{array}$ \\
\hline \multicolumn{9}{|c|}{ Ruditapes philippinarum } \\
\hline Size-class I & $\begin{array}{l}\text { AVG } \\
\text { SD }\end{array}$ & $\begin{array}{r}9.4 \\
\pm 1.4\end{array}$ & 12 & $\begin{array}{r}197 \\
\pm 79\end{array}$ & $\begin{array}{r}9.9 \\
+4.0\end{array}$ & $\begin{array}{r}19.6 \\
\pm 1.5\end{array}$ & $\begin{array}{l}26.3 \\
\pm 8.7\end{array}$ & May 1996 \\
\hline Size-class II & $\begin{array}{l}\text { AVG } \\
\text { SD }\end{array}$ & $\begin{array}{l}15.5 \\
\pm 1.0\end{array}$ & 15 & $\begin{array}{r}830 \\
\pm 174\end{array}$ & $\begin{array}{r}37.0 \\
\pm 9.2\end{array}$ & $\begin{array}{l}19.6 \\
\pm 1.5\end{array}$ & $\begin{array}{l}24.6 \\
\pm 8.8\end{array}$ & May 1996 \\
\hline Size-class III & $\begin{array}{l}\text { AVG } \\
\text { SD }\end{array}$ & $\begin{array}{r}18.9 \\
\pm 0.8\end{array}$ & 9 & $\begin{array}{r}1520 \\
\pm 149\end{array}$ & $\begin{array}{r}63.6 \\
\pm 10.4\end{array}$ & $\begin{array}{l}21.6 \\
\pm 0.3\end{array}$ & $\begin{array}{r}38.9 \\
\pm 12.8\end{array}$ & Sep 1996 \\
\hline $\begin{array}{l}\text { Musculista s } \\
\text { Size-class I }\end{array}$ & $\begin{array}{l}\text { AVG } \\
\text { SD }\end{array}$ & $\begin{array}{r}16.7 \\
\pm 1.3\end{array}$ & 14 & $\begin{array}{r}431 \\
\pm 117\end{array}$ & $\begin{array}{l}27.6 \\
\pm 7.7\end{array}$ & $\begin{array}{l}19.6 \\
\pm 1.5\end{array}$ & $\begin{array}{r}24.5 \\
\pm 9.1\end{array}$ & May 1996 \\
\hline Size-class II & $\begin{array}{l}\text { AVG } \\
\text { SD }\end{array}$ & $\begin{array}{l}23.5 \\
\pm 1.7\end{array}$ & 8 & $\begin{array}{r}1264 \\
\pm 172\end{array}$ & $\begin{array}{l}52.4 \\
\pm 8.0\end{array}$ & $\begin{array}{l}21.6 \\
\pm 0.3\end{array}$ & $\begin{array}{r}47.4 \\
\pm 22.8\end{array}$ & Sep 1996 \\
\hline
\end{tabular}

Table 1. Animals employed in the laboratory experiments and experimental conditions. Ind.: number of individuals; TOT: mean (live) weight for each size-class of the experimental animals; DW: mean soft tissue dry weight for each size-class of the experimental animals; Temp: experimental temperature; Chl a (chlorophyll a) is the mean (AVG) \pm standard deviation (SD) of 4 spikes of cultures of Thalassiosira sp. (chl $a=0.01 \times$ Thalassiosira sp. cells $+3.6, \mathrm{r}^{2}=0.91 ; \mathrm{p}<0.001, \mathrm{n}=40$ ) for each day/night treatment 


\section{Laboratory experiments}

Target species and experimental conditions

In light of the results of the field survey, we focussed our laboratory experiments on the nutrient excretion rate by Ruditapes philippinarum and Musculista senhousia, the major contributor species to the macrozoobenthic biomass on the tidal flat under investigation (Fig. 4b). We selected 3 and 2 size-classes of Ruditapes philippinarum and Musculista senhousia, respectively (Table 1), as representative of the size-class composition in the field. The DW of the soft tissues (Table 1) was used to calculate the excretion rate of each class of animals, as described in 'Materials and methods'.

Mean experimental temperature was $19.6 \pm$ 1.5 and $21.6 \pm 0.3^{\circ} \mathrm{C}$ during the experiments of May 1996 and September 1996, respectively (Table 1). The amount of food given to the different classes of animals (a total of 4 spikes for each size-class) varied from $24.5 \pm 9.1$ (sizeclass I of $M$. senhousia) to $47.4 \pm 22.8 \mu \mathrm{g} \mathrm{l}^{-1} \mathrm{chl} \mathrm{a}$ (size-class II of $M$. senhousia) (Table 1).

Food uptake and nutrient excretion rates by Ruditapes philippinarum and Musculista senhousia

In most cases, $>96 \%$ of the food (Thalassiosira sp.) offered in spikes was taken up by bivalves within the first $2 \mathrm{~h}$ after each spike (Fig. 5). This was irrespective of the amount of food given, within a range of 10 to $80 \mu \mathrm{g} \mathrm{l}^{-1} \mathrm{chl} a$, and day/night treatments in both Ruditapes philippinarum ( $\mathrm{p}>0.05, \mathrm{n}=54$ ) and Musculisca senhousia ( $\mathrm{p}>0.05, \mathrm{n}=36$ ) (Fig. 5). In contrast, in the control, the decrease of chl a content was much slower and not more than $30 \%$ of the initial content after 4 to $6 \mathrm{~h}$ (Fig. 5). Accordingly, the increase of chl a content in the control after the second spike was proportionally cumulative to the amount of food supplied with the first spike (Fig. 5).

In all light/dark treatments, the excretion of ammonium and phosphate by both Ruditapes philippinarum and Musculisca senhousia indicated a rapid increase of concentrations since the second sampling (i.e. $2 \mathrm{~h}$ after the start) (Fig. 5). Such an increase was significantly constant and linear until the end of each treatment for each size-class both in $R$. philippinarum $\left(\mathrm{r}^{2}>0.90, \mathrm{p}<\right.$ $0.001)$ and $M$. senhousia $\left(r^{2}>0.93, p<0.001\right)$. Accordingly, we used the relevant regression lines to express the animal excretion rate as representative of a day
May 9-10, 1996

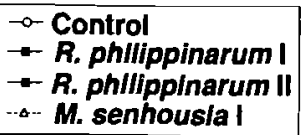

Thaiasslosira sp.
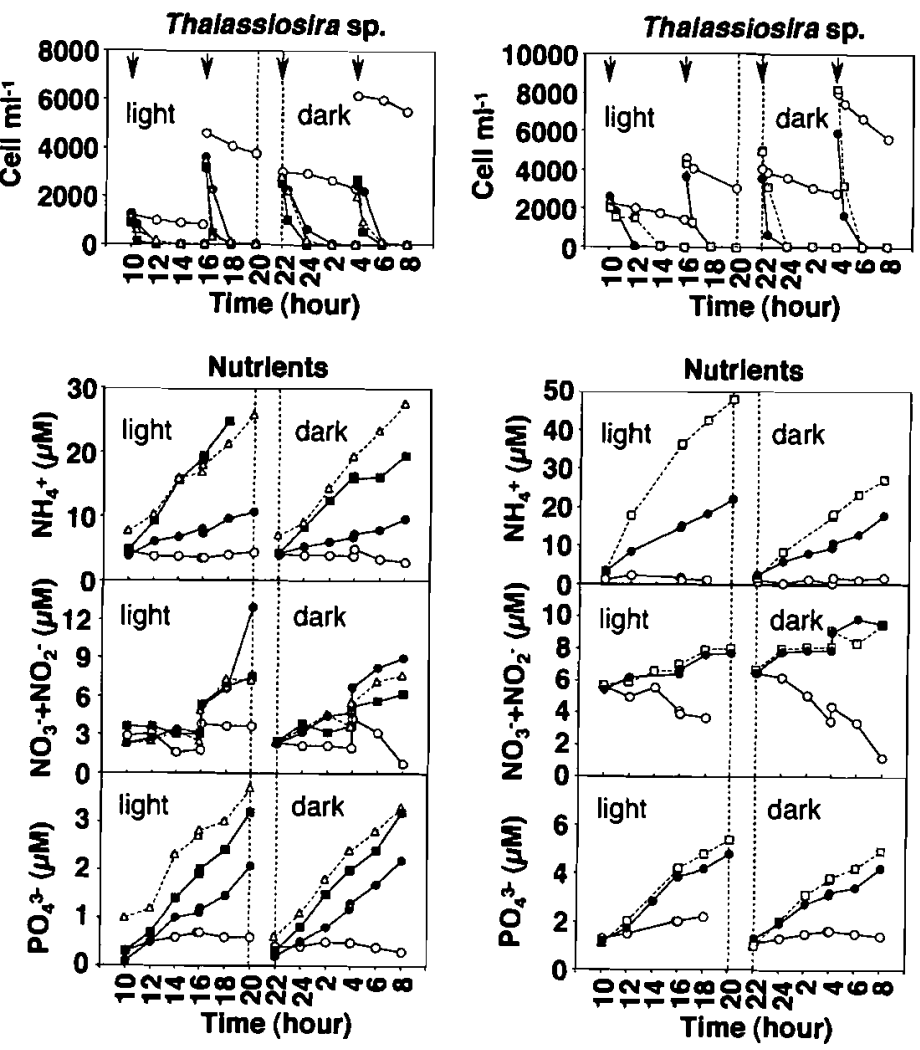

Fig. 5. Laboratory experiments: changes of food content (Thalassiosira sp.) and nutrient concentrations [ammonium, $\mathrm{NH}_{4}{ }^{+}-\mathrm{N}$; nitrate+nitrite, $\left(\mathrm{NO}_{3}{ }^{-}+\mathrm{NO}_{2}{ }^{-}\right)-\mathrm{N}$ and phosphate, $\left.\mathrm{PO}_{4}{ }^{3-}-\mathrm{P}\right]$ during the day and night treatments. Arrows indicate the times when cultures of Thalassiosira sp. were offered in spikes. Vertical dashed lines: left line (time 20:00 h) indicates the end of the day (light) treatment; right line (time 22:00 h) indicates the start of the night (dark) treatment; between lines: low tide situation between treatments (see 'Materials and methods')

(light) and night (dark) situation (Table 2). A comparison between day and night excretion rates indicated no statistically significant differences in $M$. senhousia. In contrast, we found that $R$. philippinarum excreted $45 \%$ more ammonium during the day than during the night ( $\mathrm{p}<0.001, \mathrm{n}=36$ ). In the control, ammonium and phosphate concentrations remained low (Fig. 5). The excretion of nitrate+nitrite by bivalves was in most cases not significant or much lower than that of ammonium and phosphate. However, a remarkable increase of nitrate+nitrite concentration $\left(r^{2}=0.71, p<0.05\right)$ occurred in the treatment with the smallest size-class of $R$. philippinarum (size-class I, Fig. 5). In all treatments, the sudden increase of nitrate+nitrite during the 
Table 2. Nutrient excretion rate ( $\mathrm{mol} \mathrm{g}^{-1} \mathrm{DW} \mathrm{h} \mathrm{h}^{-1}$ ) for each size-class of Ruditapes philippinarum and Musculista senhousia during day/night treatments (experimental temperature as in Table 1). ${ }^{*}$ Day (light) excretion (mean: $8.4 \mu \mathrm{mol} \mathrm{g}^{-1} \mathrm{DW} \mathrm{h}^{-1}$ ) significantly higher ( $\mathrm{p}<0.001$ ) than night (dark) excretion (mean: $5.8 \mu \mathrm{mol} \mathrm{g}^{-1} \mathrm{DW} \mathrm{h}^{-1}$ ). ns: not significant

\begin{tabular}{|c|c|c|c|c|c|c|}
\hline \multirow[t]{2}{*}{ Species } & \multicolumn{2}{|c|}{$\mathrm{NH}_{4}^{+}$} & \multicolumn{2}{|c|}{$\mathrm{NO}_{3}{ }^{-}+\mathrm{NO}_{2}^{-}$} & \multicolumn{2}{|c|}{$\mathrm{PO}_{4}{ }^{3-}$} \\
\hline & Light & Dark & Light & Dark & Light & Dark \\
\hline \multicolumn{7}{|c|}{ Ruditapes philippinarum } \\
\hline Size-class I & 10.6 & 7.9 & 12.3 & 7.6 & 3.4 & 3.9 \\
\hline Size-class Il & 9.6 & 5.8 & ns & 0.9 & 1.0 & 1.1 \\
\hline Size-class III & 5.0 & 3.8 & ns & ns & 0.9 & 0.7 \\
\hline Mean & \multicolumn{2}{|c|}{$7.1^{*}$} & \multicolumn{2}{|c|}{3.5} & \multicolumn{2}{|c|}{1.9} \\
\hline \multicolumn{7}{|c|}{ Musculista senhousia } \\
\hline Size-class I & 9.3 & 11.4 & 1.8 & 1.9 & 1.2 & 1.5 \\
\hline Size-class II & 16.9 & 9.7 & ns & ns & 1.6 & 1.3 \\
\hline Mean & \multicolumn{2}{|c|}{11.8} & \multicolumn{2}{|c|}{0.9} & \multicolumn{2}{|c|}{1.4} \\
\hline
\end{tabular}

second food spike (i.e. ca $2 \mu \mathrm{mol}$ in May experiment at $16: 00 \mathrm{~h}$ and $04: 00 \mathrm{~h}$ ) was artificial, as due to the medium addition. In the control, we assume that the progressive decrease of nitrate+nitrite concentration was caused by phytoplankton uptake. Such a decrease was indeed most evident after the second spike of food, in the night treatment, when the phytoplankton biomass was doubled (Fig. 5).

The fluxes of nitrogen $(\mathrm{N})$ and phosphorus $(\mathrm{P})$, calculated from the nutrient concentrations at each sampling time; were highly correlated with each other in both Ruditapes philippinarum $\left(\mathrm{r}^{2}=0.841, \mathrm{p}<0.001, \mathrm{n}=\right.$ 29) and Musculisca senhousia $\left(\mathrm{r}^{2}=0.715, \mathrm{p}<0.001, \mathrm{n}=\right.$ 19) (Fig. 6). The N/P mean ratios for $R$. philippinarum and $M$. senhousia were $7.8 \pm 3.0$ and $9.9 \pm 3.5$, respectively.

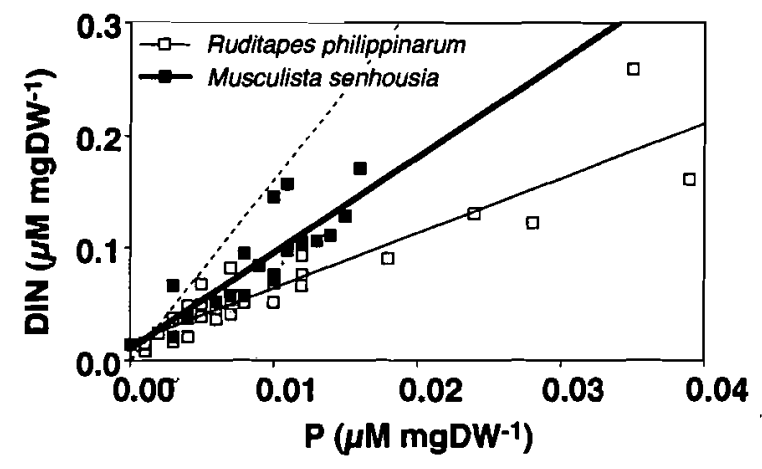

Fig. 6. Relationship between dissolved inorganic nitrogen $\left[\left(\mathrm{DIN}=\mathrm{NH}_{4}{ }^{+} \mathrm{N}+\left(\mathrm{NO}_{3}{ }^{-}+\mathrm{NO}_{2}{ }^{-}\right)-\mathrm{N}\right]\right.$ and phosphate $\left(\mathrm{PO}_{4}{ }^{3-}-\mathrm{P}\right)$ concentrations measured during the time course of the laboratory experiments. Each value refers to the $\mathrm{N}$ and $\mathrm{P}$ concentrations measured at each sampling interval $(2 \mathrm{~h})$ multiplied by the water volume and divided by the total DW biomass of the experimental bivalves (see 'Material and methods'). The DIN/P linear regression lines for Ruditapes philippinarum and Musculista senhousia are $y=4.86 x+0.02, \mathrm{r}^{2}=0.841$ (thin solid line, $\mathrm{p}<0.001, \mathrm{n}=29$ ) and $y=8.49 \mathrm{x}+0.01, \mathrm{r}^{2}=0.715$ (thick solid line, $\mathrm{p}<0.001, \mathrm{n}=19$ ), respectively. Dashed line: Redfield et al. (1963) N:P ratio (N:P=16:1)

\section{Estimation of the nutrient excretion by macrozoobenthos in the field}

To quantify the regeneration of nutrients through the excretory activity of macrozoobenthos on the tidal flat under investigation, we used for each bivalve species the mean of the 6 (Ruditapes philippinarum) and 4 (Musculisca senhousia) excretion rates obtained in our laboratory experiments (Table 2). According to the temperatures recorded during the field survey (Fig. 3), we employed these values as representative of the excretion rate by bivalves on the tidal flat during April, May, June and October (Table 3). At lower and higher temperatures, we corrected the excretion rates obtained in our laboratory experiments to take into account the changes in the physiological energetics of bivalves with temperature (Bayne \& Scullard 1977, Mann \& Glomb 1978, Nakamura et al. 1988). For the clam $R$. philippinarum, we calculated the nutrient excretion rates at temperatures other than $20^{\circ} \mathrm{C}$ based on the results obtained by Goulletquer et al. (1989), who investigated the temperature-dependent seasonal change of ammonium excretion rates by $R$. philippinarum and presented a nonlinear model where the rate of respiration has a maximum value at $20^{\circ} \mathrm{C}$. Accordingly, we calculated 3 other excretion rates for temperature values of 5,15 and $25^{\circ} \mathrm{C}$ (Table 3). For the Mytilida M. senhousia, we calculated the nutrient excretion at 5,15 and $25^{\circ} \mathrm{C}$ from the rates of oxygen uptake and ammonium excretion of the mussel Mytilus edulis (de Vooys 1976, Bayne \& Scullard 1977, Schlüter \& Josefsen 1994), as no published data in this regard are available for $M$. senhousia (Table 3). Although changes in nutrient excretion rate by bivalves also occur in relation to reproductive condition and food availability (Bayne 1973, Mann 1979, Goulletquer et al. 1989, Cockcroft 1990, Smaal et al. 1997), we infer that an additional manipulation of the actual excretion rates would introduce inaccuracy. In addition, we found that the calculation of bivalve excre- 
Table 3. Adopted temperature-dependent excretion rates for Ruditapes philippinarum and Musculista senhousia. A factor ( $f$ ) of 1 is used for the mean of the excretion rates obtained during our laboratory experiments (Table 2). Factors at other temperatures are calculated from Goulletquer et al. (1989) for $R$. philippinarum, and de Vooys (1976), Bayne \& Scullard (1977) and Schlüter \& Josefsen (1994) for $M$. senhousia. $\mathrm{NO}_{\mathbf{x}}$ : $\left(\mathrm{NO}_{3}{ }^{-}+\mathrm{NO}_{2}{ }^{-}\right)-\mathrm{N}$

\begin{tabular}{|c|c|c|c|c|c|c|c|c|c|c|c|c|}
\hline \multirow[t]{2}{*}{ Months } & & \multicolumn{3}{|c|}{ Temperature $\left({ }^{\circ} \mathrm{C}\right)$} & \multicolumn{8}{|c|}{ Excretion rate $\left(\mu \mathrm{mol} \mathrm{g} \mathrm{g}^{-1} \mathrm{DW} \mathrm{h}^{-1}\right)$} \\
\hline & & Stns B5-B1 & Stn $H 1$ & Stn $Y 3$ & $f$ & $\begin{array}{l}\text { R. phill } \\
\mathrm{NH}_{4}{ }^{+}\end{array}$ & $\begin{array}{l}\text { pinart } \\
\mathrm{NO}_{x}\end{array}$ & $\mathrm{PO}_{4}{ }^{3-}$ & $f$ & $\begin{array}{l}\text { M. sen } \\
\mathrm{NH}_{4}{ }^{+}\end{array}$ & $\begin{array}{l}\text { housia } \\
\mathrm{NO}_{x}\end{array}$ & $\mathrm{PO}_{4}{ }^{3-}$ \\
\hline $\begin{array}{l}\text { Dec, Jan, } \\
\text { Feb }\end{array}$ & $\begin{array}{l}\text { AVG } \\
\text { SD }\end{array}$ & $\begin{array}{r}4.7 \\
\pm 1.8\end{array}$ & $\begin{array}{r}5.9 \\
\pm 1.8\end{array}$ & $\begin{array}{r}10.4 \\
\pm 2.1\end{array}$ & 0.6 & 4.3 & 2.3 & 1.1 & 0.5 & 5.9 & 0.5 & 0.7 \\
\hline Nov, Mar & $\begin{array}{c}\text { AVG } \\
\text { SD }\end{array}$ & $\begin{array}{r}11.7 \\
\pm 0.9\end{array}$ & $\begin{array}{r}11.9 \\
\pm 0.2\end{array}$ & $\begin{array}{r}15.2 \\
\pm \mathbf{3 . 0}\end{array}$ & 0.9 & 6.4 & 3.2 & 1.7 & 0.7 & 8.26 & 0.6 & 1.0 \\
\hline $\begin{array}{l}\text { Apr, May, } \\
\text { Jun, Oct }\end{array}$ & $\begin{array}{c}\text { AVG } \\
\text { SD }\end{array}$ & $\begin{array}{r}19.6 \\
\pm 2.8\end{array}$ & $\begin{array}{r}19.9 \\
\pm 4.0\end{array}$ & $\begin{array}{r}21.7 \\
\pm 3.6\end{array}$ & 1 & 7.1 & 3.5 & 1.9 & 1 & 11.8 & 0.9 & 1.4 \\
\hline $\begin{array}{l}\text { Jul, Aug, } \\
\text { Sep }\end{array}$ & $\begin{array}{l}\text { AVG } \\
\text { SD }\end{array}$ & $\begin{array}{r}27.7 \\
\pm 2.3\end{array}$ & $\begin{array}{r}28.0 \\
\pm 3.1\end{array}$ & $\begin{array}{r}26.9 \\
\pm 1.1\end{array}$ & 0.9 & 6.4 & 3.2 & 1.7 & 1.2 & 14.2 & 1.1 & 1.7 \\
\hline
\end{tabular}

tion rates using relatively different factors did not markedly vary the seasonal pattern of animal nutrient excretion due to the strong temporal change of bivalve biomass. Thus, using the biomass monthly values found in the field (Fig. 4b), we estimated the daily excretion rate over a 2 yr period for each nutrient species (Fig. 7). The highest excretion was that of ammonium, up to $35.2 \mathrm{mmol} \mathrm{m}^{-2} \mathrm{~d}^{-1}$, in August 1994. To a lesser but noticeable extent was the excretion of nitrate+nitrite and phosphate. In addition, the temporal fluctuation of nutrient fluxes through excretion was strong, with a 25 fold increase in 1994 (from April to August) and a 12fold increase in 1995 (from February to September). Nutrient excretion due to bivalve excretion was highest from July to September in 1994 and from August to November in 1995 (Fig. 7).

\section{Diffusive fluxes from the sediments}

The vertical profiles of nutrient concentrations in the porewater showed rather marked distributional and seasonal patterns (Fig. 8). Ammonium and phosphate tended to increase from the surface $(0-0.5 \mathrm{~cm})$ to the $4-5 \mathrm{~cm}$ layer and from January (winter) to October (autumn). Concentrations varied from $75.1(0-0.5 \mathrm{~cm}$, January) to $508 \mu \mathrm{mol} \mathrm{NH}_{4}{ }^{+}-\mathrm{N}(4-5 \mathrm{~cm}$, October), and from $0.89\left(0-0.5 \mathrm{~cm}\right.$, January) to $27.6 \mu \mathrm{mol} \mathrm{PO}_{4}{ }^{3}-\mathrm{P}(3-4 \mathrm{~cm}$, October). In contrast, nitrate+nitrite concentrations rapidly decreased with depth in all seasons. The highest $(9.0 \mu \mathrm{M})$ and lowest $(0.58 \mu \mathrm{M})$ nitrate+nitrite concentrations occurred in October at the surface and in the 4-5 cm layer, respectively. Based on the relevant linear regression line obtained from these vertical profiles (surface sediment to $5 \mathrm{~cm}$ depth), we calculated the diffusive fluxes of nutrients. We found no flux for phosphate in April and July and in all seasons for nitrate+

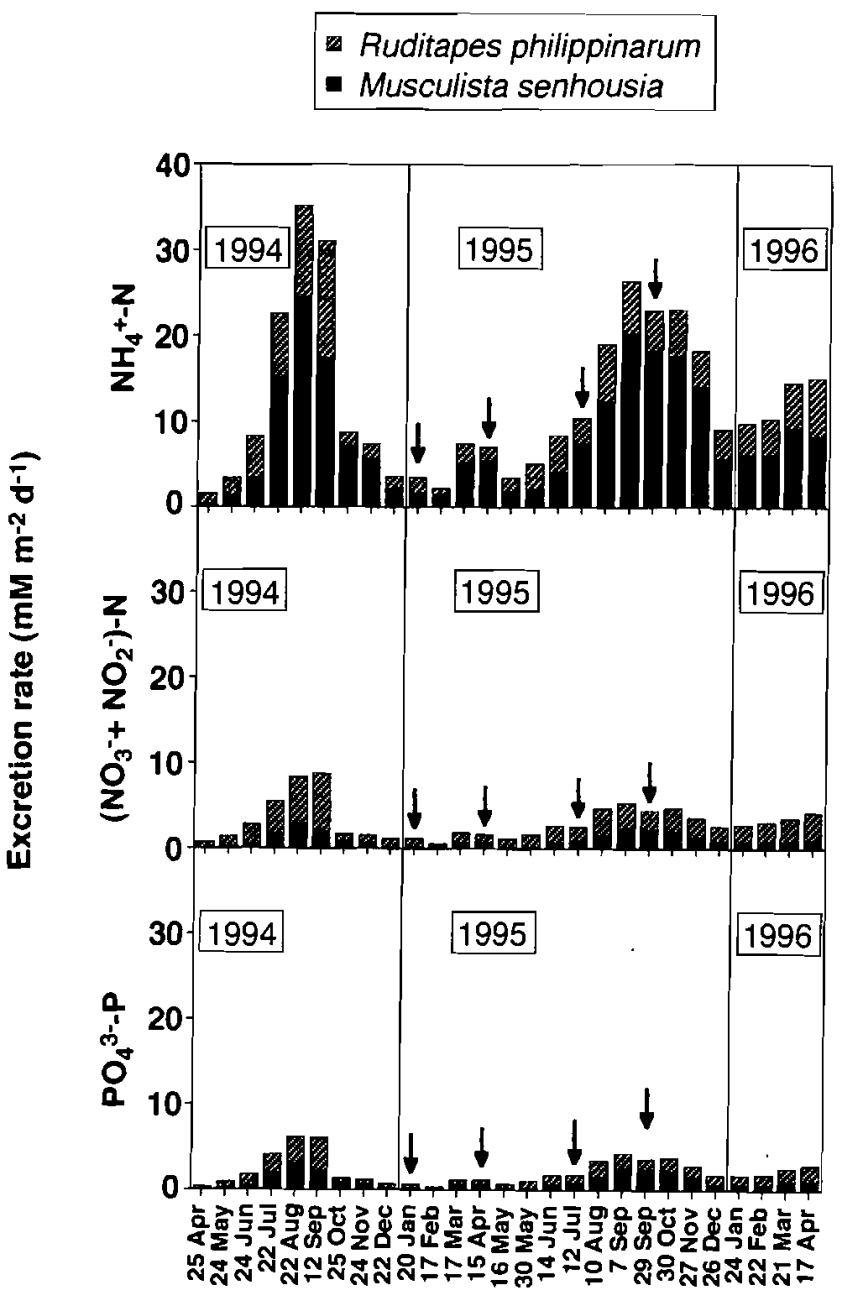

Fig. 7. Temporal change of nutrients excretion by Ruditapes philippinarum and Musculista senhousia in the study area. Arrows: approximate periods when nutrient concentrations in the porewater were measured (Fig. 8) and the diffusive upward flux was calculated (Table 4) 


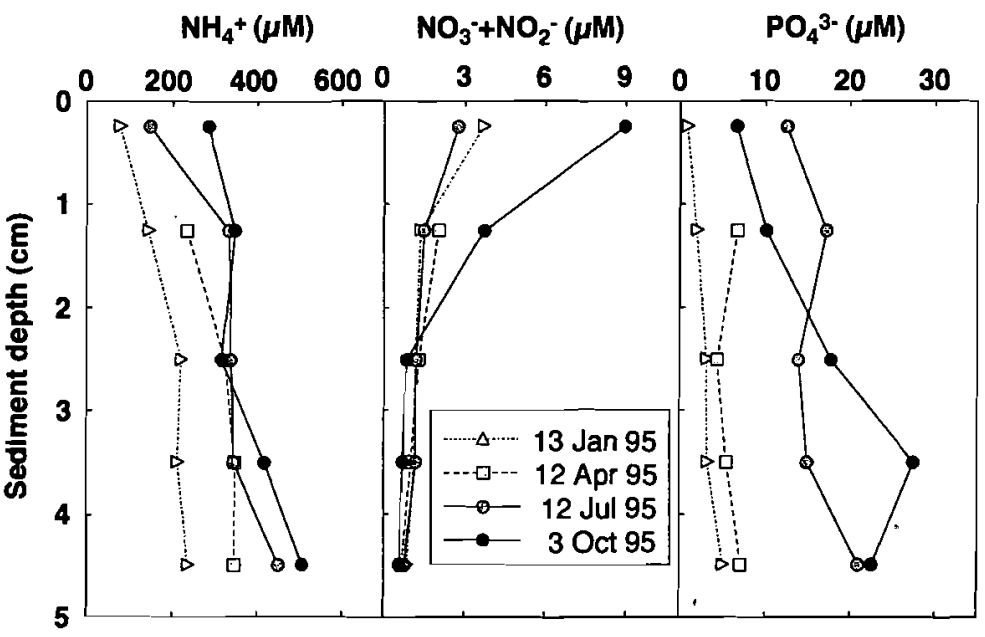

Fig. 8. Vertical profile of porewater nutrient concentrations in the uppermost $5 \mathrm{~cm}$ of intertidal sediments in all 4 seasons

nitrite (Fig. 8). As Table 4 summarizes, both biogenic and diffusive fluxes of ammonium and phosphate were low in winter (January) and spring (April), and higher in summer (July) and autumn (September-October). Yet, the temporal variability of the biogenic nutrient flux was stronger than that of the diffusive flux (i.e. ammonium, Table 4).

\section{DISCUSSION}

The presence of Ruditapes philippinarum and Musculista senhousia in our study area may be regarded as a typical feature of bivalve composition in intertidal and temperate coastal zones of Japan (Ohba 1959, Tanaka \& Kikuchi 1978, Sekiguchi et al. 1995). Both $R$. philippinarum and $M$. senhousia have recently gained much attention worldwide. $R$. philippinarum, a hardshelled clam native to Asia and popular in the Japanese fishery (Okutani et al. 1985), has rapidly became the subject of great interest during the last decade in mollusk farming in the USA and Europe (Thompson 1995, Edwards 1997, Goulletquer \& Heral 1997). $M$. senhousia, a thin-shelled mytilid also native to Asia, is referred to as an opportunistic species which has invaded various intertidal and subtidal soft sediments of the world (Crooks 1996, Hayward et al. 1997). Its significant effects on habitat alteration (typically forming compact mat patches) and community levels have been recently highlighted by Creese et al. (1997) and Crooks (1998). Accordingly, much work on $R$, philippinarum and $M$. senhousia has been conducted on related commercial and ecological aspects, respectively. However, in spite of the wide spread of natural populations of $R$. philippinarum and $M$. senhousia in tidal estuaries around the world, little work has focussed on their possible role in the processes of nutrient regeneration (Reusch \& Williams 1998). Few laboratory studies are available on the excretion of ammonium by $R$. philippinarum (Table 5) and no data are available for $M$. senhousia. In our laboratory experiments, the excretion rates of ammonium by $R$. philippinarum were higher than those previously reported by Mann \& Glomb (1978), Mann (1979) and Xie \& Burnell (1995), but comparable to those reported by Langton et al. (1977) and Goulletquer et al. (1989) (Table 5). Overall, a comparison with previous studies on bivalve ammonium excretion indicated that the rates we obtained for both $R$. philippinarum and $M$. senhousia are among the highest recorded in laboratory experiments for clam and mussel species, respectively (Table 5). Goulletquer et al. (1989) also showed that the excretion of organic nitrogen by $R$. philippinarum may represent a major portion of the total nitrogen excretion. It is accordingly true that, in addition to the direct excretion of ammonium, bacterial mineralization of organic nitrogen produced by the bivalves themselves may occur. Our results for ammonium excretion rates by $R$. philippinarum, which are within the same range as those reported by Goulletquer et al. (1989), suggest a negligible effect of this process in our experiments. We also infer that bacterial mineralization would have been increasingly noticeable through the course of the incubation, possibly causing a more irregular and/or exponential increase of ammonium concentration toward the end of each treatment. This was not observed, but ammonium concentrations rapidly increased

Table 4. Extent of calculated nutrient fluxes from the sediments $\left(\mathrm{mmol} \mathrm{m}^{-2} \mathrm{~d}^{-1}\right)$ : bivalve excretion (Excr) and diffusional fluxes (Diff) according to the Fick's first law

\begin{tabular}{|lrccccc|}
\hline \multicolumn{1}{l}{ Date } & \multicolumn{2}{c}{$\mathrm{NH}_{4}{ }^{+}$} & \multicolumn{2}{c}{$\mathrm{NO}_{3}{ }^{-}+\mathrm{NO}_{2}{ }^{-}$} & \multicolumn{2}{c}{$\mathrm{PO}_{4}{ }^{3-}$} \\
& Excr & Diff & Excr & Diff & Excr & Diff \\
\hline 13 Jan 1995 & & 0.213 & & - & & 0.002 \\
20 Jan 1995 & 3.4 & & 1.0 & & 0.65 & \\
12 Apr 1995 & & 0.203 & & - & & - \\
15 Apr 1995 & 7.0 & & 1.6 & & 1.1 & \\
12 Jul 1995 & 10.3 & 0.353 & 2.8 & - & 1.7 & - \\
29 Sep 1995 & 22.9 & & 5.1 & & 3.4 & 0.010 \\
3 Oct 1995 & & 0.279 & & - & & \\
\hline
\end{tabular}




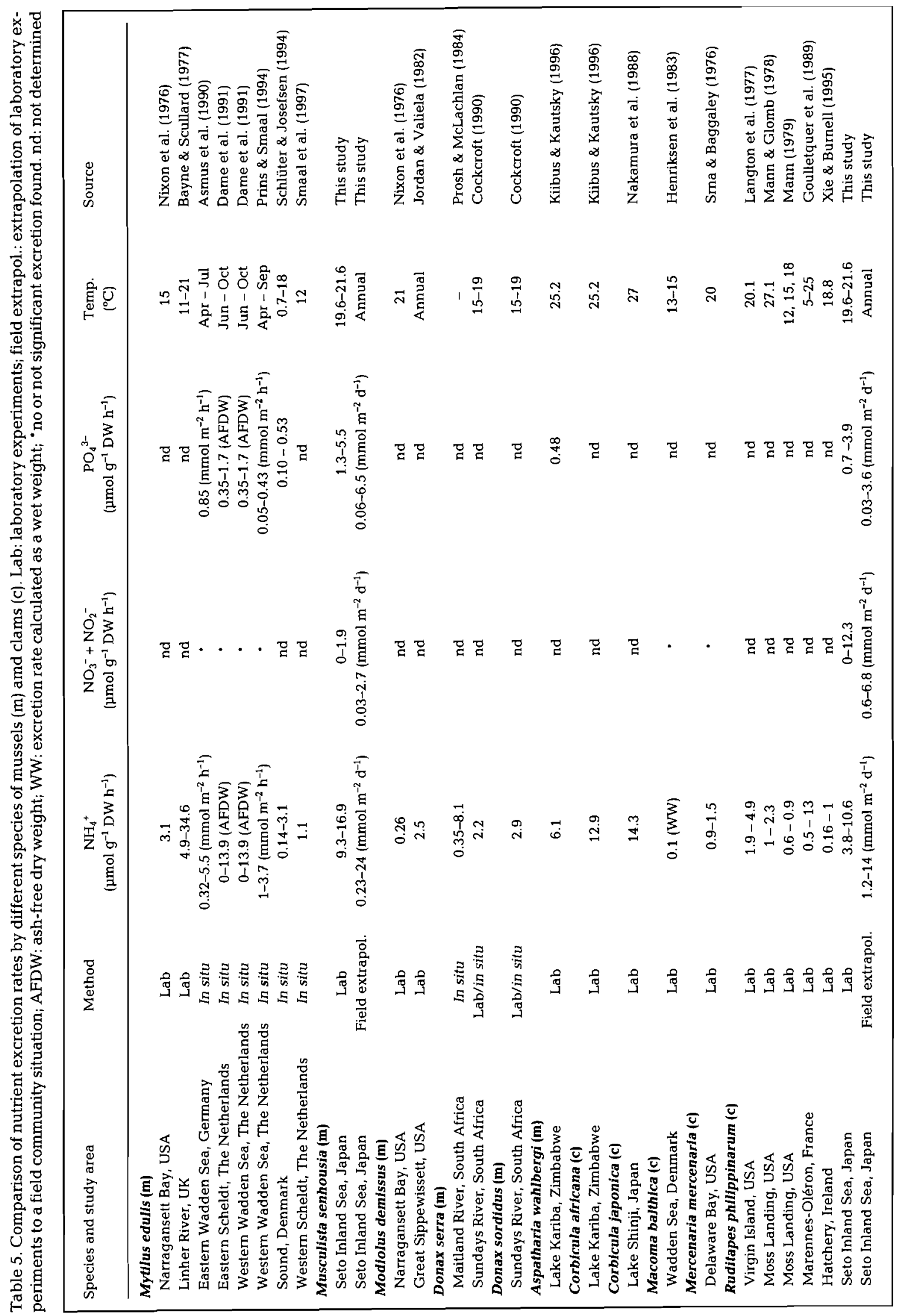


after the first $2 \mathrm{~h}$ and showed a significant linearity $(p<0.001)$ until the end of all treatments (Fig. 5). Further, significant differences in ammonium flux between day and night treatments for $R$. philippinarum ( $45 \%$ higher flux in the day, $\mathrm{p}<0.001)$ would be unlikely to be due to the effect of bacterial activity. In addition, such differences were not significant for $M$. senhousia, making an effect of bacterial mineralization in our experimental design further unlikely. In the control, ammonium (and phosphate) concentrations remained low, in spite of a high algal biomass in suspension which might have progressively enhanced bacterial activity as well.

Table 5 also shows that most previous laboratory studies on the nutrient excretion by clams and mussels have selectively focussed on ammonium. The excretion of nitrate+nitrite by bivalve species has commonly been neglected or found to be not significant (Table 5). Downward flux (sediment uptake) of nitrate+nitrite is usually observed (Dame \& Dankers 1988, Dame et al. 1991, Feuillet-Girard et al. 1997), related to denitrification and/or nitrate ammonification processes (Trimmer et al. 1998, Usui et al. 1998). Occasional release of nitrate+nitrite from the sediments has been related to microbial nitrification (Henriksen et al. 1983, Prins \& Smaal 1994). In our laboratory experiments, the excretion of nitrate+nitrite by size-classes II and III of Ruditapes philippinarum and by Musculisca senhousia was not significant or accounted only for a minor part of the DIN (dissolved inorganic nitrogen) (Table 2). These results are thus in agreement with previous observations on similarly sized or larger bivalves commonly employed in both laboratory and field experiments. In contrast, the smallest size-class of $R$. philippinarum (shell length $9.4 \pm 1.4 \mathrm{~mm}$, Table 1) excreted as much nitrate+nitrite as ammonium (Table 2), suggesting that young populations of $R$. philippinarum can have an important role in supplying both nitrogen species.

Until now little work has investigated the parallel excretion of ammonium and phosphate by intertidal bivalves (limited to 1 dominant species) and presented the relevant N/P stoichiometry (Prins \& Smaal 1994). In our experiments, the high ammonium flux found for both bivalve species and for all size-classes coincided with a highly significant linear increase of phosphate $(p<0.001)$. The subsequent significant correlation of DIN and P fluxes in both Ruditapes philippinarum and Musculisca senhousia $(p<0.001)$ (Fig. 6) demonstrated that these bivalve species are able to recycle rapidly and efficiently the dissolved forms of 2 major bioelements such as nitrogen and phosphorus.

It can be also noted that most laboratory and in situ measurements of macrozoobenthos excretion rate have been conducted over short period incubations (i.e. 1 to 2 h) (Nakamura et al. 1988, Gardner et al. 1993, Prins \& Smaal 1994). Even on longer incubátions (Kiibus \& Kautsky 1996, Asmus et al. 1998), the difference between start and end values has been used to calculate the animal excretion rate. As such, the field-relevant excretory potential rate of each macrozoobenthos species might not be quantified. This may also represent a major drawback in applying the results to a field $(24 \mathrm{~h})$ situation, thus limiting the quantification of animal excretion on a hourly basis. To prevent these limitations, we extended our laboratory experiments over a period $(10 \mathrm{~h})$ which was representative of the duration of sediment submersion in the field $(10 \mathrm{~h})$. During each incubation, we collected, at regular intervals, several samples to allow a more reliable quantification of bivalve excretion on a daily basis. This also allowed us to verify possible differences in bivalve nutrient excretion rates between day and night. This aspect has also seldom been considered before, but the higher excretion of ammonium during the day by $R$. philippinarum strongly suggests a day/night (light/dark) influence on the excretory activity by $R$. philippinarum which will need further investigation.

Overall, much work on the nutrient excretion by bivalves has been carried out through laboratory experiments (Table 5). Relatively few studies have been extrapolated to populations of animals. The abovementioned difficulties in extrapolating short-period incubation data on bivalve excretion rates to a field situation have been further complicated by a considerable lack of extended information on the distribution of natural populations of macrozoobenthos. In intertidal zones, major results with regard to this aspect have been obtained on mussel beds of Mytilus edulis (Dame \& Dankers 1988, Prins \& Smaal 1994, Smaal \& Zurburg 1997 ) and oyster reefs of Crassostrea virginica (Dame et al. 1984) and C. gigas (Smaal \& Zurburg 1997) using in situ open-flow tunnels. The ammonium excretion by mussel beds of $M$. edulis was 2.7 to $7.8 \mathrm{mmol} \mathrm{m}^{-2} \mathrm{~h}^{-1}$ ( 37.8 to $109 \mathrm{mmol} \mathrm{m}^{-2} \mathrm{~d}^{-1}$ ) in the western Wadden Sea, The Netherlands (Dame \& Dankers 1988), $1 \mathrm{mmol} \mathrm{m}^{-2}$ $\mathrm{h}^{-1}\left(20 \mathrm{mmol} \mathrm{m}^{-2} \mathrm{~d}^{-1}\right)$ in Marennes Oléron, south-west France (Smaal \& Zurburg 1997), and 1 to $3.7 \mathrm{mmol} \mathrm{m}^{-2}$ $\mathrm{h}^{-1}$ (18 to $\left.66.6 \mathrm{mmol} \mathrm{m}^{-2} \mathrm{~d}^{-1}\right)$ in the Western Scheldt, The Netherlands (Prins \& Smaal 1994). These values are among the highest for ammonium release from intertidal sediments due to animal excretion. In these experiments dense assemblages of mussels were employed whose biomass varied from 511-899 g AFDW (ash-free dry weight) $\mathrm{m}^{-2}$ (Smaal \& Zurburg 1997) to $890-2190 \mathrm{~g} \mathrm{AFDW} \mathrm{m}^{-2}$ (Prins \& Smaal 1994). İt can be argued that these biomass values are much higher than those otherwise commonly reported for natural populations of intertidal macrozoobenthos. In Balgzand, west- 
ern Wadden Sea, the macrozoobenthic biomass varies between 30 and $50 \mathrm{~g} \mathrm{AFDW} \mathrm{m}^{-2}$ (Beukema 1992); in Arcachon Bay, south-west France, it ranges between 11.5 and $22.8 \mathrm{~g} \mathrm{DW} \mathrm{m}^{-2}$ (Castel et al. 1989, Bachelet \& Dauvin 1993). It can be inferred that the excretion rates obtained in the above-mentioned field experiments would represent the maximum potential release of nutrients by intertidal macrozoobenthos. In our study, the biomass of Ruditapes philippinarum and Musculisca senhousia (annual mean $71.3 \mathrm{~g} \mathrm{DW} \mathrm{m}^{-2}$ ) was much lower than that of dense assemblages of $M$. edulis. However, it was $>5$ times higher than the mean biomass of macrozoobenthos in the Seto Inland Sea, estimated as $56.1 \mathrm{~g}$ WW $\mathrm{m}^{-2}$ (Hashimoto et al. 1997). Combining the information gained from our field survey and the laboratory experiments, our estimation of ammonium excretion by $M$. senhousia and $R$. philippinarum was up to 1217 and $545 \mu \mathrm{mol} \mathrm{m} \mathrm{m}^{-2} \mathrm{~h}^{-1}$, respectively (August 1994). This corresponded to an ammonium excretion rate of $35.2 \mathrm{mmol} \mathrm{m}^{-2} \mathrm{~d}^{-1}$ (Fig. 7), thus comparable to the highest releases of ammonium reported for mussel beds and oyster reefs. Such high biogenic ammonium regeneration, well balanced by that of phosphate (Fig. 6), will have a major impact on primary producers, such as microphytobenthos (Magni \& Montani 1997), within the intertidal zone. We might further speculate that regenerated $\mathrm{N}$ and $\mathrm{P}$ by macrozoobenthos might be also an important source of nutrients to macroalgae (Ulva sp.), which rapidly and massively develop in our study area during the irradiated and warm period (Magni \& Montani 1998, 2000).

The temporal change of the biomass of Ruditapes philippinarum and Musculisca senhousia (Fig. 4b) indicated that the release of nutrients by natural populations of intertidal macrozoobenthos may vary strongly through the year (Fig. 7). The present study and our associated work point to the high degree of variability in these systems (Magni \& Montani 1997, 1998, 2000, Montani et al. 1998). It is true that extrapolating controlled laboratory measurements to populations of animals in the field might involve some limitations. For instance, the seasonal variation in the composition and availability of algal material will differently affect bivalve condition and performance, i.e. physiological state (Goulletquer et al. 1989) and filtration rates (Prins et al. 1994). In our experiments, algal food was offered in spikes to ensure a good performance by the experimental animals. The amount of algal food used in these experiments was field relevant in order to give further significance to our extrapolation of laboratory measurements to field populations. In an associated piece of work conducted along a tidal creek on the intertidal zone of the present study area, we investigated the seasonal patterns of nutrients and particulate compounds over the same
2 yr period (Magni \& Montani 2000). The algal biomass offered to the experimental animals (water temperature 20 to $22^{\circ} \mathrm{C}$ ) was based on our field observations and approximated for a spring-summer (i.e. May to October, mean water temperature $23.5 \pm 4.2^{\circ} \mathrm{C}$ ) algal content (Magni \& Montani 2000). We found that both photosynthetic pigment (chl $a$ and pheopigments) and particulate organic carbon (POC) contents were 3 to 4 times lower during the cold period (i.e. November to April, mean water temperature $10.4 \pm 4.4^{\circ} \mathrm{C}$ ) (Magni \& Montani 2000). This implies that the extent of the temporal scaling of biogenic nutrient flux from the sediments due to bivalve excretion might be even greater in relation to potential food limitation, as well as loss of body mass (Fig. 2), in winter. On the other hand, the temporal distribution of macrozoobenthos was large enough to limit potential confounding factors in extrapolating laboratory measurements to field populations due to additional field variables, such as seasonal variation of food availability.

Our laboratory experiments and temporal scaling of bivalve excretion were restricted to the inorganic forms of nitrogen $\left[\mathrm{NH}_{4}{ }^{+}-\mathrm{N}\right.$ and $\left.\left(\mathrm{NO}_{3}{ }^{-}+\mathrm{NO}_{2}{ }^{-}\right)-\mathrm{N}\right]$ and phosphorus $\left(\mathrm{PO}_{4}{ }^{3-}-\mathrm{P}\right)$. Previous studies indicated that dissolved organic nitrogen (DON) is also an important product of macrozoobenthos excretion. Cockcroft (1990) found that ammonium and amino acids constituted 75 and $25 \%$ of the total dissolved nitrogen (TDN) excreted by the bivalves Donax spp., respectively. Lomstein et al. (1989) demonstrated that a high macrofaunal biomass was correlated with high rates of gross urea production, high concentrations of urea and ammonium, and high sediment-water exchange rates of urea and ammonium. They found that the flux of urea from samples collected during 2 cruises accounted for $47 \%$ in Bering Shelf-Anadyr sediment and $70 \%$ in Alaska Coastal sediment of the total urea + $\mathrm{NH}_{4}{ }^{+}+\mathrm{NO}_{3}{ }^{-}+\mathrm{NO}_{2}{ }^{-}$flux from the sediment. Goulletquer et al. (1989) investigated the excretion of organic nitrogen (urea + amino acids) and $\mathrm{NH}_{4}{ }^{+}$by experimental individuals of Ruditapes philippinarum on a seasonal basis. They found that the contribution of urea + amino acid excretion to the total urea + amino acids + $\mathrm{NH}_{4}{ }^{+}$varied widely through the year from ca 40 to $90 \%$. Our quantification of macrofaunal excretory flux highlighted that extended field surveys on the animal standing stock and its temporal distribution should be considered of primary relevance when studying the contribution of macrozoobenthos to the processes of nutrient regeneration, in addition to the variation in excretion rate due to seasonal cycles of gametogenesis, storage and utilization of body reserves (Bayne 1973, Mann 1979, Goulletquer et al. 1989, Cockcroft 1990, Smaal et al. 1997). Such variability will also play a major role in determining the quantitative relevance of 
the seasonal variation of inorganic (i.e. ammonium) and organic (i.e. urea) nitrogen forms deriving from bivalve excretion, which has been shown to vary to different extents through the year (Boucher \& BoucherRodoni 1988, Goulletquer et al. 1989).

To evaluate the relative contribution of macrozoobenthos excretion to the fluxes of nutrients from the sediments several approaches and explanations have been presented. Prins \& Smaal (1994) calculated the ammonium excretion by mussels in a Benthic Ecosystem Tunnel by the difference between the total nutrient fluxes and the activity of mussel beds. This accounted for 17 to $94 \%$ and 31 to $85 \%$ of the ammonium and phosphate, respectively. In mesocosm experiments, Doering et al. (1987) found that the level of flux was elevated in the presence of Mercenaria mercenaria by $57 \%$ for ammonium. Boucher \& BoucherRodoni (1988) estimated that oyster beds contributed to an average of $37 \%$ of the ammonium flux. In our study, both the biogenic flux from the sediments due to animal excretion (Fig. 7) and the nutrient concentrations in the porewater (Fig. 8) showed a marked seasonal pattern. Recently, Reush \& Williams (1998) demonstrated a positive relationship between sediment ammonium concentration and Musculisca senhousia density in a sandy subtidal zone in San Diego Bay. Our subsequent paper will focus on this aspect and assess the relationship between the temporal variability of macrozoobenthic communities and that of nutrient concentrations in the porewater in our study area (Magni et al. unpubl.). In the present study, our Fickian flux calculations were made from nutrient porewater gradients using a conventional method (i.e. coring/ centrifugation) at a resolution of 0.5 to $1 \mathrm{~cm}$ depth horizons. We acknowledge that the low resolution of our calculations is likely to lead to an underestimation of in situ diffusive flux due to smaller scale local events, e.g. burrow channelling of surface water to depth, which can be more properly evaluated with high-resolution porewater profiles provided, for instance, by gel probe sampling (Mortimer et al. 1999). In addition, the high variability of these systems, i.e. tidal currents and wind-generated waves (Nakamura 1994, Miller-Way \& Twilley 1996, Asmus et al. 1998), may enhance the upward diffusive flux of nutrients, thus making it difficult to directly apply our results to a particular and realtime condition. Accordingly, we did not attempt to compare individual calculated diffusive flux values with bivalve excretion not directly measured but extrapolated from laboratory experiments. Our results suggest, for our study area, a larger extent of the temporal variability of nutrient flux due to animal excretion than that due to molecular diffusion calculated from the nutrient concentrations in the porewater (i.e. ammonium, Table 4). In addition, we found that both nutrient concentrations in the porewater and the extent of nutrient regeneration through diffusive flux in our study area were quite comparable to those reported for adjacent intertidal and coastal areas where in situ benthic chambers have been used (Kuwae et al. 1998) and the effect of tidal exchange taken into account (Matsukawa et al. 1987). In the eutrophic Seto Inland Sea, where the tidal flat of the present study is located, the benthic fluxes of nitrogen and phosphorus reportedly range from 0.242 to $1.00 \mathrm{mmol} \mathrm{m}^{-2} \mathrm{~d}^{-1}$ and from 0.009 to $0.045 \mathrm{mmol} \mathrm{m}^{-2} \mathrm{~d}^{-1}$, respectively (Yamamoto et al. 1998). In Aburatsubo Bay, a semienclosed inlet adjacent to Tokyo Bay, $\mathrm{N}$ and $\mathrm{P}$ fluxes range from 0.210 to $1.49 \mathrm{mmol} \mathrm{m}^{-2} \mathrm{~d}^{-1}$ and from 0.008 to $0.031 \mathrm{mmol} \mathrm{m}^{-2} \mathrm{~d}^{-1}$, respectively (Takayanagi \& Yamada 1999). Similar values are reported from other intertidal flats of Japan (Matsukawa et al. 1987, Kuwae et al. 1998). Whereas little information about the distribution of macrozoobenthos and no data regarding their relevant rates of nutrient excretion were given, the major impact of biogenic flux on the total nutrient flux was strongly suggested. For instance, Kuwae et al. (1998) found on an intertidal sand flat of Tokyo Bay that the diffusive flux obtained by the ammonium profile explained only $22 \%$ of the source flux directly measured in the dark $\left(1.1 \mathrm{mmol} \mathrm{m}^{-2} \mathrm{~d}^{-1}\right)$. They hypothesized that bioturbation or excretion by macrozoobenthos, dominated by the polychaetes Armandia sp. and Ruditapes philippinarum, greatly contributed to the exchange flux. The present study indicates that the effect of nutrient biogenic flux may indeed have major relevance in the cycling of $\mathrm{N}$ and $\mathrm{P}$ both in intertidal zones (Matsukawa et al. 1987, Kuwae et al. 1998) and in eutrophic coastal waters, such as the Seto Inland Sea (Yamamoto et al. 1998). In addition, our results pointed to the strong and direct influence of the temporal fluctuation of animal biomass on the benthic biogenic regeneration of $\mathrm{N}$ and $\mathrm{P}$. We conclude that in our study area the dominant bivalve species $R$. philippinarum and $M$. senhousia play a primary role in the year-round processes of benthic nutrient regeneration and thus act as a major factor supporting primary producers within the intertidal zone.

Acknowledgements. We gratefully acknowledge Dr S. Pithakpol, Laboratory of Environmental Oceanography, Kagawa University, for making available Thalassiosira sp. cultures and for his assistance during the laboratory experiments. We extend our thanks to Messrs. M. Harada and T. Sezaki from the same laboratory for their cooperation in collecting the macrozoobenthos samples during the field work. We are also grateful to several referees for constructive and helpful criticisms on early drafts of this manuscript. P.M. was supported by a European Union Science \& Technology Fellowship Programme in Japan (EU S\&T FPJ contract no. ERB IC17 CT980046) during the writing of this paper. 


\section{LITERATURE CITED}

Aller RC (1988) Benthic fauna and biogeochemical processes: the role of borrow structures. In: Blackburn TH, Sørensen $\mathrm{J}$ (eds) Nitrogen cycling in coastal marine environments. Wiley, Chichester, p 301-338

Asmus H, Asmus RM, Reise K (1990) Exchange processes in an intertidal mussel bed: a Sylt-flume study in the Wadden Sea. Ber Biol Anstalt Helgol 6

Asmus RM, Asmus H, Wille A, Zubillaga GF, Reise K (1994) Complementary oxygen and nutrient fluxes in seagrass beds and mussels banks? In: Dyer KR, Orth RJ (eds) Changes in fluxes in estuaries: implications from science to management. Olsen \& Olsen, Fredensborg, p 227-238

Asmus RM, Asmus H, Wille A, Zubillaga GF, Reise K (1998) The role of water movement and spatial scaling for measurements of dissolved inorganic nitrogen fluxes in intertidal sediments. Estuar Coast Shelf Sci 46:221-232

Bachelet G, Dauvin JC (1993) Distribution quantitative de la macrofauna benthique des sables intertidaux du bassin d'Arcachon. Oceanol Acta 16:83-97

Bayne BL (1973) Physiological changes in Mytilus edulis L. induced by temperature and nutritive stress. J Mar Biol Assoc UK 53:39-58

Bayne BL, Scullard C (1977) Rates of nitrogen excretion by species of Mytilus (Bivalvia: Mollusca). J Mar Biol Assoc UK 57:355-369

Berner RA (1980) Early diagenesis. A theoretical approach. Princeton University Press, Princeton

Beukema JJ (1992) Long-term and recent changes in the benthic macrofauna living on tidal flats in the Western part of the Wadden Sea. Neth Inst Sea Res Publ Ser 20:135-141

Boucher G, Boucher-Rodoni R (1988) In situ measurements of respiratory metabolism and nitrogen fluxes at the interface of oyster beds. Mar Ecol Prog Ser 44:229-238

Callender E, Hammond DE (1982) Nutrient exchange across the sediment-water interface in the Potomac river estuary. Estuar Coast Shelf Sci 15:395-413

Castel J, Labourg PJ، Escaravage V, Auby l, Garcia ME (1989) Influence of seagrass beds and oyster parks on the abundance and biomass patterns of meio- and macrobenthos in tidal flats. Estuar Coast Shelf Sci 28:71-85

Cockcroft AC (1990) Nitrogen excretion by the surf zone bivalves Donax serra and D. sordidus. Mar Ecol Prog Ser 60:57-65

Creese R, Hooker S, De Luca S, Wharton Y (1997) Ecology and environmental impact of Musculista senhousia (Mollusca: Bivalvia: Mytilidae) in Tamaki Estuary, Auckland, New Zealand. NZ J Mar Freshw Res 31:225-236

Crooks JA (1996) The population ecology of an exotic mussel, Musculista senhousia, in a southern California Bay. Estuaries 19:42-50

Crooks JA (1998) Habitat alteration and community-level effects of an exotic mussel, Musculista senhousia. Mar Ecol Prog Ser 162:137-152

Dame RF, Dankers N (1988) Uptake and release of materials by a Wadden Sea mussel bed. J Exp Mar Biol Ecol 118: 207-216

Dame RF, Zingmark RG, Haskin E (1984) Oyster reefs as processors of estuarine materials. J Exp Mar Biol Ecol 83: 239-247

Dame RF, Dankers N, Prins T, Jongsma H, Smaal A (1991) The influence of mussel beds on nutrients in the western Wadden Sea and Eastern Scheldt estuaries. Estuaries 14: 130-138

de Vooys (1976) The influence of temperature and time of year on the oxygen uptake of the sea mussel Mytilus edulis. Mar Biol 36:25-30

Doering PH, Kelly JR, Oviatt CA, Sowers T (1987) Effect of the hard clam Mercenaria mercenaria on benthic fluxes of inorganic nutrients and gases. Mar Biol 94:377-383

Edwards E (1997) Molluscan fisheries in Britain. NOAA Tech Report NMFS 129:85-99

Falcao M, Vale C (1990) Study of the Rio Formosa ecosystem: benthic nutrient remineralization and tidal variability of nutrients in the water. Hydrobiologia 207:137-146

Feuillet-Girard M, Gouleau D, Blanchard G, Joassard L (1997) Nutrient fluxes on an intertidal mudflat in MarennesOléron Bay, and influence of the emersion period. Aquat Living Resour 10:49-58

Gardner WS, Briones EE, Kaegi EC, Rowe GT (1993) Ammonium excretion by benthic invertebrates and sedimentwater nitrogen flux in the Gulf of Mexico near the Mississippi river outflow. Estuaries 16:799-808

Gómez-Parra A, Forja JM (1993) Benthic fluxes in Cadiz Bay (SW Spain). Hydrobiologia 252:23-34

Goulletquer P, Heral M (1997) Marine molluscan production trends in France: from fisheries to aquaculture. NOAA Tech Report NMFS 129:137-164

Goulletquer P, Heral M, Deslous-Paoli JM, Prou J, Garnier J, Razet D, Boromthanarat W (1989) Ecophysiologie et bilan énergétique de la palourde japonaise d'élevage Ruditapes philippinarum. J Exp Mar Biol Ecol 132:85-108

Hashimoto $H_{1}$ Hashimoto $T$, Matsuda $O$, Tada $K$, Tamai $K$, Uye S, Yamamoto T (1997) Biological productivity of lower trophic levels of the Seto Inland Sea. In: Okaichi T, Yanagi $T$ (eds) Sustainable development in the Seto Inland Sea, Japan - from the viewpoint of fisheries. Terra Publishing Company, Tokyo, p 17-58

Hayward BW, Stephenson AB, Morley M, Riley JL, Grenfell HR (1997) Faunal changes in Waitemata Harbour sediments, 1930s-1990s. J R Soc NZ 27:1-20

Henriksen K, Rasmussen MB, Jensen A (1983) Effect of bioturbation on microbial nitrogen transformations in the sediment and fluxes of ammonium and nitrate to the overlaying water. Environ Biogeochem 35:193-205

Jordan TE, Valiela I (1982) A nitrogen budget of the ribbed mussel, Geukensia demissa, and its significance in nitrogen flow in a New England salt marsh. Limnol Oceanol 27: 75-90

Kiibus M, Kautsky N (1996) Respiration, nutrient excretion and filtration rate of tropical freshwater mussels and their contribution to production and energy flow in Lake Kariba, Zimbabwe. Hydrobiologia 331:25-32

Klump JV, Martens CS (1983) Benthic nitrogen regeneration. In: Carpenter EJ, Capone DG (eds) Nitrogen in the marine environment. Academic Press, New York, p 411-457

Krom MD, Berner RA (1980) The experimental determination of the diffusion coefficients of sulfate, ammonium, and phosphate in anoxic marine sediments. Limnol Oceanogr 25:327-337

Kuwae T, Hosokawa Y, Eguchi N (1998) Dissolved inorganic nitrogen cycling in Banzu intertidal sand-flat, Japan. Mangroves Salt Marshes 2:167-175

Langton RW, Haines KC, Lyon RE (1977) Ammonia-nitrogen production by the bivalve mollusc Tapes japonica and its recovery by the red seaweed Hypnea musciformis in a tropical mariculture system. Helgol Wiss Meeresunters 30: 217-229

Lomstein BA, Blackburn TH, Henriksen K (1989) Aspects of nitrogen and carbon cycling in the northern Bering Shelf sediment: I. The significance of urea turnover in the mineralization of ammonium ion. Mar Ecol Prog Ser 57:237-248

Lorenzen CJ (1967) Determination of chlorophyll and pheopigments: spectrophotometric equations. Limnol Oceanogr 12:343-346

Luther GW III, Brendel PJ, Lewis BL, Sundby B, Lefrançois L, Silverberg N, Nuzzio DB (1998) Simultaneous measure- 
ments of $\mathrm{O}_{2}, \mathrm{Mn}, \mathrm{Fe}_{1} \mathrm{I}^{-}$, and $\mathrm{S}(-\mathrm{II})$ in marine pore waters with a solid-state voltammetric microelectrode. Limnol Oceanogr 43:325-333

Magni P (1998) A multidisciplinary study on the dynamics of biophilic elements $(C, N, P, S i)$ in a tidal estuary of the Seto Inland Sea, Japan: physicochemical variability and macrozoobenthic communities. $\mathrm{PhD}$ thesis, The United Graduated School of Ehime University

Magni P, Montani S (1997) Development of benthic microalgal assemblages on an intertidal flat in the Seto Inland Sea, Japan: effects of environmental variability. La Mer 35:137-148

Magni P, Montani S (1998) Responses of intertidal and subtidal communities of the macrobenthos to organic load and oxygen depletion in the Seto Inland, Japan. J Rech Océanogr 23:47-56

Magni P, Montani S (2000) Water chemistry variability in the lower intertidal zone of a tidal estuary in the Seto Inland Sea, Japan: seasonal patterns of dissolved and particulate compounds. Hydrobiolia (in press)

Mann R (1979) The effect of temperature on growth, physiology, and gametogenesis in the Manila clam Tapes philippinarum (Adams \& Reeve, 1850). J Exp Mar Biol Ecol 38: $121-133$

Mann R, Glomb SJ (1978) The effect of temperature on growth and ammonia excretion of the Manila clam Tapes japonica. Estuar Coast Shelf Sci 6:335-339

Matsukawa Y, Sato Y, Sasaki K (1987) Benthic flux of nutrient salts on an intertidal flat. Nippon Suisan Gakkaishi 53: 985-989

Miller-Way T, Twilley RR (1996) Theory and operation of continuous flow systems for the study of benthic-pelagic coupling. Mar Ecol Prog Ser 140:257-269

Montani S, Magni P, Shimamoto M, Abe N, Okutani K (1998) The effect of a tidal cycle on the dynamics of nutrients in a tidal estuary in the Seto Inland Sea, Japan. J Oceanogr $54: 65-76$

Mortimer RJG, Davey JT, Krom MD, Watson PG, Frickers PE Clifton RJ (1999) The effect of macrofauna on porewater profiles and nutrient fluxes in the intertidal zone of the Humber estuary. Estuar Coast Shelf Sci 48:683-699

Murphy RC, Kremer JN (1985) Bivalve contribution to benthic metabolism in a California lagoon. Estuaries 8:330-341

Nakamura M, Yamamuro M, Ishikawa M, Nishimura H (1988) Role of the bivalve Corbicula japonica in the nitrogen cycle in a mesohaline lagoon. Mar Biol 99:369-374

Nakamura Y (1994) Effect of flow velocity on phosphate release from sediment. Water Sci Technol 30:263-272

Nixon SW (1981) Remineralization and nutrient cycling in coastal marine ecosystems. In: Nelson B, Cronbin LE (eds) Nutrient enrichment in estuaries. Humana Press, Clifton, NJ, p 111-138

Nixon SW, Oviatt CA, Garber J, Lee V (1976) Diel metabolism and nutrient dynamics in a salt marsh embayment. Ecology 57:740-750

Ohba S (1959) Ecological studies in the natural population of a clam, Tapes japonica, with special reference to seasonal variations in the size and structure of the population and to individual growth. Biol J Okayama Univ 5:13-47

Okutani T, Tomiyama T, Hibiya T (1985) Fisheries in Japan. Bivalves. Japan Marine Products Photo Material Association, Tokyo

Parsons TR, Maita M, Lalli CM (1984) A manual of chemical and biological methods for seawater analysis. Pergamon Press, Oxford

Prins TC, Smaal AC (1990) Benthic-pelagic coupling: the release of inorganic nutrients by an intertidal bed of Mytilus edulis. In: Barnes M, Gibson RN (eds) Trophic relationships in the marine environment. Proc 24th Eur Mar Biol Symp. Aberdeen Univ Press, Aberdeen, p 89-103

Prins TC, Smaal AC (1994) The role of the blue mussel Mytilus edulis in the cycling of nutrients in Oosterschelde estuary (the Netherlands). Hydrobiologia 282/283: 413-429

Prins TC, Dankers N, Smaal AC (1994) Seasonal variation in the filtration rates of a semi-natural mussel bed in relation to seston composition. J Exp Mar Biol Ecol 176:69-86

Prosh RM, McLachlan A (1984) The regeneration of surf-zone nutrients by the sand mussel, Donax Serra Röding. J Exp Mar Biol Ecol 80:221-233

Redfield AC, Ketchum BH, Richards FA (1963) The influence of organisms on the composition of sea-water. In: Hill NM (ed) The sea, Vol 2. Wiley-Interscience, New York, p 26-77

Reusch TBH, Williams SL (1998) Variable responses of native eelgrass Zostera marina to a non-indigenous bivalve Musculista senhousia. Oecologia 113:428-441

Ricciardi A, Bourget E (1998) Weight to weight conversion factors for marine benthic invertebrates. Mar Ecol Prog Ser 163:245-251

Risgaard-Petersen N, Rysgaard S, Nielsen LP, Revsbech NP (1994) Diurnal variation of denitrification and nitrification in sediments colonized by benthic microphytes. Limnol Oceanogr 39:573-579

Rizzo WM (1990) Nutrient exchanges between the water column and a subtidal benthic microalgal community. Estuaries $13: 219-226$

Rowe GT, Clifford CH, Smith KL, Hamilton PL (1975) Benthic nutrient regeneration and its coupling to primary productivity in coastal waters. Nature 225:215-217

Schlüter L, Josefsen SB (1994) Annual variation in condition, respiration and remineralisation of Mytilus edulis $\mathrm{L}$. in the Sound, Denmark. Helgol Meeresunters 48:419-430

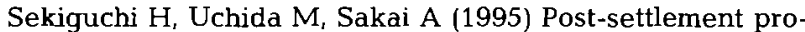
cesses determining the features of bivalve assemblages in tidal flats. Benthos Res 49:1-14

Smaal AC, Zurburg W (1997) The uptake and release of suspended and dissolved material by oysters and mussels in Marennes-Oléron Bay. Aquat Living Resour 10:23-30

Smaal AC, Vonck APMA, Bakker M (1997) Seasonal variation in physiological energetics of Mytilus edulis and Cerastoderma edule of different size classes. J Mar Biol Assoc UK 77:817-838

Snra RF, Baggaley A (1976) Rate of excretion of ammonia by the hard clam Mercenaria mercenaria and the american oyster Crassostrea virginica. Mar Biol 36:251-258

Strickland JDH, Parsons TR (1972) A practical handbook of seawater analysis. Bull Fish Res Boàrd Can 167

Sundbäck K, Enoksson V, Granéli W, Pettersson K (1991) Influence of sublittoral microphytobenthos on the oxygen and nutrient flux between sediment and water: a laboratory continuous-flow study. Mar Ecol Prog Ser 74:263-279

Takayanagi $\mathrm{K}$, Yamada $\mathrm{H}$ (1999) Effects of benthic flux on short term variations of nutrients in Aburatsubo Bay. J Oceanogr 55:463-469

Tanaka M, Kikuchi T (1978). Ecological studies on benthic macrofauna in Tomoe Cove, Amakusa. II. Production of Musculista senhousia (Bivalvia, Mytilidae). Publ Amakusa Mar Biol Lab 4:215-233

Thompson DS (1995) Substrate additive studies for the development of hardshell clam habitat in waters of Puget Sound in Washington State: an analysis of effects on recruitment, growth, and survival of the Manila clam, Tapes philippinarum, and on the species diversity and abundance of existing benthic organisms. Estuaries 18:91-107

Trimmer M, Nedwell DB, Sivyer DB, Malcolm SJ (1998) Nitro- 
gen fluxes through the lower estuary of the river Great Ouse, England: the role of the bottom sediments. Mar Ecol Prog Ser 163:109-124

Usui T, Koike I, Ogura N (1998) Tidal effect on dynamics of pore water nitrate in intertidal sediment of a eutrophic estuary. J Oceanogr 54:205-216

van Duyl FC, van Raaphorst W, Kop AJ (1993) Benthic bacterial production and nutrient sediment-water exchange in sandy North Sea sediments. Mar Ecol Prog Ser 100:85-95

Xie Q, Burnell GM (1995) The effect of activity on the physiological rates of two clam species, Tapes philippinarum (Adams \& Reeve) and Tapes decussatus (Linnaeus). Biol Environ Proc Royal Irish Acad 95B:217-223

Editorial responsibility: Otto Kinne (Editor), Oldendorf/Luhe, Germany
Yamada H, Kayama M (1987) Liberation of nitrogenous compounds from bottom sediments and effect of bioturbation by small bivalve, Theora lata (Hinds). Estuar Coast Shelf Sci 24:539-555

Yamamoto T, Matsuda O, Hashimoto T, Imose H, Kitamura T (1998) Estimation of benthic fluxes of dissolved inorganic nitrogen and phosphorus from sediments of the Seto Inland Sea. Umi to Kenkyu (Oceanogr Soc Jpn) 7:151-158 (in Japanese)

Yamamuro M, Koike I (1993) Nitrogen metabolism of the filter-feeding bivalve Corbicula japonica and its significance in primary production of a brackish lake in Japan. Limnol Oceanogr 35:997-1007

Submitted: May 28, 1999; Accepted: October 18, 1999 Proofs received from author(s): May 19, 2000 